TOMASZ RachWAE

Akademia Pedagogiczna, Kraków

\title{
Problematyka badawcza funkcjonowania przedsiębiorstw przemysłowych
}

Procesy transformacji gospodarczej w Polsce, zachodzące pod wpływem nasilających się procesów globalizacji, wpływają w zasadniczym stopniu na gruntowne zmiany funkcjonowania poszczególnych sektorów gospodarki narodowej, przedsiębiorstw przemysłowych i usługowych oraz instytucji. W efekcie dochodzi do przebudowy struktur przemysłowych, która dokonuje się w wyniku zmian funkcjonowania przedsiębiorstw przemysłowych, traktowanych jako podstawowe elementy przestrzennych form koncentracji przemysłu. W centralnym systemie sterowania przedsiębiorstwa przemysłowe funkcjonowały $\mathrm{w}$ warunkach gospodarki planowej, przejawiającej się w wykonywaniu zadań wyznaczonych przez plany jednostek nadrzędnych, co wpływało na ograniczenie samodzielności przedsiębiorstw w zakresie zasobów majątkowych, wielkości i asortymentu produkcji, kierunków zbytu, zaopatrzenia w surowce i materiały, struktur organizacyjnych, zatrudnienia, a także kierunków rozwoju. W stosunkowo niewielkim stopniu sprzyjało to modernizacji procesów produkcji, podnoszeniu jakości asortymentu produkcji i wdrażaniu innowacji. We wprowadzanym systemie gospodarki rynkowej w otoczeniu przedsiębiorstw pojawiły się nowe uwarunkowania ich funkcjonowania, a mechanizmy konkurencji zaczęły mieć istotne znaczenie w zmianach kierunku działalności przedsiębiorstw oraz ich selekcji. Proces dostosowania się przedsiębiorstw przemysłowych do tych nowych warunków gospodarowania wymaga od nich przeprowadzenia głębokich zmian w funkcjonowaniu, prowadzących do podniesienia ich konkurencyjności. Zmiany te warunkują uczestnictwo krajowych przedsiębiorstw przemysłowych w globalnych procesach gospodarczych i integrację polskiego przemysłu z przemysłem światowym, zwłaszcza w drodze powiązań organizacyjnych, kapitałowych, technologicznych i wchodzenia w ukształtowane sieci rynkowe ponadnarodowych korporacji. Dlatego też z punktu widzenia analizy procesu transformacji gospodarczej w Polsce, w szczególności transformacji struktur przemysłowych, istotna wydaje się problematyka badawcza funkcjonowania poszczególnych przedsiębiorstw przemysłowych. 


\section{RÓŻNICE W PODEJŚCIU DO PROBLEMATYKI BADAWCZEJ FUNKCJONOWANIA PRZEDSIĘBIORSTW PRZEMYSŁOWYCH}

\section{W NAUKACH GEOGRAFICZNYCH I EKONOMICZNYCH}

Problematyka badawcza funkcjonowania przedsiębiorstw przemysłowych nawiązuje do współczesnego nurtu badań geografii ekonomicznej, w którym na czołową pozycję wysuwa się problematyka restrukturyzacji różnej skali układów przestrzennych - od skali lokalnej i ponadlokalnej przez skalę subregionalną i regionalną po skalę europejską i światową. W procesach tych, jak zauważa wielu autorów (m.in. Chojnicki 1996; Domański 1997; Dutkowski, Michalski, Sagan, Stryjakiewicz 1999; Gierańczyk 2006, Kostrubiec 2006, May 2008, Mikołajewicz 2001; Misztal 1997; Pakuła 2003, Parysek 1994, Pączka 1994a, 1994b; Rydz, Szymańska 2002; Stryjakiewicz 1994, 1998, 1999, 2001; Tobolska 2006, Tkocz 2001, Wiedermann 2008, Wieloński 2003, Zioło 1992, 1999, 2000, 2001, 2003, 2006a, 2006b, 2008), wiodącą rolę odgrywa problematyka przemian struktury przestrzennej przemysłu, a szczególnie ich podstawowych elementów, jakimi są przedsiębiorstwa przemysłowe. T. Stryjakiewicz (1999) zauważa, że badania geograficzne procesów transformacji przemysłu dotyczą przede wszystkim zróżnicowania tego procesu w ujęciu regionalnym, odczuwa się więc brak opracowań próbujących wniknąć głębiej w mechanizm adaptacji przedsiębiorstw do nowych warunków gospodarowania i trendów globalnych. Opinię tę potwierdza M. Tkocz (2001), zwracając dodatkowo uwagę na fakt, że badania geograficzne dotyczące procesów restrukturyzacji w Polsce nie mają do tej pory wykształconych podstaw teoretycznych ani metodologicznych. Na brak badań nad funkcjonowaniem przedsiębiorstw zwraca także uwagę B. Domański (1997), który wskazuje, że geografia przedsiębiorstw jest ważnym, ale niedocenianym nurtem polskiej geografii ekonomicznej, i zauważa konieczność jej rozwoju.

Należy zaznaczyć, że problematyka restrukturyzacji przedsiębiorstw w procesie transformacji jest jednym $\mathrm{z}$ wiodących problemów badawczych podejmowanych na gruncie nauk ekonomicznych. Dominuje tam jednak specjalistyczne podejście do wybranych aspektów funkcjonowania przedsiębiorstwa, np. polityki ustalania cen (Klamecka-Roszkowska 1999), usprawnienia rachunku kosztów (Dyhdalewicz 1999), działalności promocyjnej (Langer 1998), jakości produkcji (Sieniawska 1994), zmian struktury zatrudnienia i sprzedaży (Chomątowska, Waligórska 1996), zbytu (Polanowski 1991), struktury kosztów (Kudełko 1994), kosztów kapitału (Kasiewicz 2001), decyzji inwestycyjnych (Kwaśny 1997) i in. Na szczególną uwagę zasługują tu także prace zbiorowe pod red. R. Borowieckiego (1992, 1996, 1997, 1998, 1999a, 1999b, 2003), które w znacznej części poświęcone są właśnie problematyce wybranych aspektów funkcjonowania przedsiębiorstw w procesie transformacji. W kompleksowych badaniach nad restrukturyzacją przedsiębiorstw, pozwalających na formułowanie uogólnień, prowadzonych na gruncie nauk ekonomicznych w skali kraju lub regionów (Sudoł, Karaszewski 1996, Sudoł, Matuszak 2002; Mączyńska 2001, Stępień 2001), również zwraca się uwagę przede wszystkim na wskaźniki ekonomiczno-finansowe, restrukturyzację majątkową, produktową i restrukturyzację zatrudnienia, natomiast pomija lub marginalizuje przestrzenne aspekty działalności przedsiębiorstw. Niemniej należy się zgodzić z T. Stryjakiewiczem (1999), że prace powstałe na gruncie nauk ekonomicznych stanowią cenne źródło danych statystycznych i poszerzają możliwość interpretacji. W ostatnim czasie obserwuje się jednak pewne zbliżenie podejmowanej problematyki badawczej 
przez ekonomistów i geografów ekonomicznych, które przejawia się w podejmowaniu przez tych pierwszych w szerszym zakresie zagadnień przestrzennych w funkcjonowaniu przedsiębiorstw oraz zwracaniu większej uwagi przez geografów na aspekty ekonomiczne, w tym strukturę kosztów i kształtowanie się wyników finansowych, przy analizie funkcjonowania przedsiębiorstw. Takie zbliżenie należy uznać za bardzo korzystne z punktu widzenia podejmowanego przedmiotu badań, chociaż w niektórych środowiskach jest niesłusznie traktowane jako ,zawłaszczanie” problematyki badawczej ${ }^{1}$.

W pracy badawczej nad funkcjonowaniem przedsiębiorstw przemysłowych wyjątkowo potrzebne wydaje się więc podjęcie problemu całościowych zmian funkcjonowania przedsiębiorstw, osadzonych w konkretnej przestrzeni geograficznej. Istotnym zagadnieniem badawczym są więc zmiany powiązań przestrzennych przedsiębiorstwa i jego wpływu na otoczenie. Podejście to zostało zweryfikowane w podjętej przez autora pracy badawczej, której przedmiotem były zmiany funkcjonowania wybranych przedsiębiorstw przemysłowych Polski Południowo-Wschodniej w okresie transformacji systemowej polskiej gospodarki.

\section{UWARUNKOWANIA PROCESU ZMIAN FUNKCJONOWANIA PRZEDSIĘBIORSTW}

Podjęcie problematyki badawczej funkcjonowania przedsiębiorstw przemysłowych w okresie transformacji gospodarczej wymaga analizy zewnętrznych i wewnętrznych uwarunkowań ich funkcjonowania. Wśród uwarunkowań zewnętrznych podstawową rolę odgrywają uwarunkowania międzynarodowe związane z nasilającym się procesem globalizacji działalności gospodarczej i integracji europejskiej, przejawiające się m.in. w napływie bezpośrednich inwestycji zagranicznych (tab. 1). Do uwarunkowań zewnętrznych zaliczono także uwarunkowania krajowe, wynikające z polityki przemysłowej państwa, przejawiające się m.in. w kształtowaniu instrumentów prawnych, prowadzonej polityki gospodarczej, w tym procesu prywatyzacji przedsiębiorstw oraz tworzeniu i wdrażaniu strategii restrukturyzacji określonych branż przemysłu. Do podstawowych uwarunkowań wewnętrznych zaliczono podatność przedsiębiorstw na procesy zmian funkcjonowania, wynikającą m.in. z przynależności branżowej, struktury wielkościowej, postaw pracowników wobec zmian i jakości zarządzania, charakteru struktury organizacyjnej, stopnia zacofania technologicznego, zadłużenia i dostępności do źródeł zasilania finansowego, powiązań rynkowych z otoczeniem.

Tabela 1. Uwarunkowania procesu transformacji przedsiębiorstw przemysłowych

\begin{tabular}{|c|l|l|}
\hline \multicolumn{2}{|c|}{ ZEWNĘTRZNE } & \multicolumn{1}{c|}{ WEWNĘTRZNE } \\
\hline $\begin{array}{l}\text { wynikające z otoczenia } \\
\text { międzynarodowego }\end{array}$ & $\begin{array}{l}\text { wynikające z otoczenia kra- } \\
\text { jowego }\end{array}$ & $\begin{array}{l}\text { wynikające ze struktury przedsiębiorstwa } \\
\text { i charakteru jego powiązań z otoczeniem } \\
\text { u progu transformacji gospodarczej }\end{array}$ \\
\hline $\begin{array}{c}\text { - procesy koncentracji } \\
\text { kapitału oraz integra- } \\
\text { cyjne przedsiębiorstw, } \\
\text { - wzrost znaczenia kor- } \\
\text { poracji międzynarodo- } \\
\text { wych, }\end{array}$ & $\begin{array}{l}\text { - wdrażane regulacje praw- } \\
\text { no-administracyjne związane } \\
\text { ze zmianą systemu gospodar- } \\
\text { czego i harmonizowaniem } \\
\text { prawa gospodarczego w } \\
\text { związku z integracją z UE, }\end{array}$ & $\begin{array}{l}\text { - przynależnośc branżowa (działowa), } \\
\text { stopień przerostu zatrudnienia, } \\
\text { - charakter struktury i kultury organiza- } \\
\text { cyjnej, } \\
\text { - struktury zatrudnienia, w szczególności } \\
\text { struktura wykształcenia załogi, }\end{array}$ \\
\hline
\end{tabular}

${ }^{1}$ Szerzej na ten temat w artykule P. Czaplińskiego w niniejszym tomie. 


\begin{tabular}{|c|c|c|}
\hline $\begin{array}{l}\text { - wzrost konkurencji na } \\
\text { rynku globalnym, } \\
\text { - przepływy bezpośred- } \\
\text { nich inwestycji zagra- } \\
\text { nicznych, } \\
\text { - procesy delokalizacji } \\
\text { i relokacji przedsię- } \\
\text { biorstw, } \\
\text { - szybki postęp techno- } \\
\text { logiczny, szczególnie } \\
\text { w dziedzinie technolo- } \\
\text { gii informacyjnej, } \\
\text { - gospodarowanie } \\
\text { oparte na wiedzy, pro- } \\
\text { wadzące do wzrostu } \\
\text { znaczenia zaawanso- } \\
\text { wanych prac badaw- } \\
\text { czo-rozwojowych i } \\
\text { innowacji, } \\
\text { - procesy integracyjne } \\
\text { państw i regionów, w } \\
\text { tym proces integracji } \\
\text { europejskiej. }\end{array}$ & $\begin{array}{l}\text { - tempo, zakres i ścieżki } \\
\text { (uwarunkowania prawne) } \\
\text { prywatyzacji przedsię- } \\
\text { biorstw państwowych, } \\
\text { - otwarcie rynku polskiego, } \\
\text { w tym rynku kapitałowego, } \\
\text { na napływ przedsiębiorstw } \\
\text { zagranicznych, towarów } \\
\text { i kapitału, } \\
\text { - zakres i instrumenty oddzia- } \\
\text { ływania w zakresie polityki } \\
\text { gospodarczej, w szcze- } \\
\text { gólności polityki przemy- } \\
\text { słowej, } \\
\text { - tworzenie i wdrażanie stra- } \\
\text { tegii restrukturyzacji okre- } \\
\text { ślonych branż przemysłu, } \\
\text { - polityka państwa w zakresie } \\
\text { oświaty, nauki i wdrażania } \\
\text { innowacji, szczególnie } \\
\text { w odniesieniu do wymiany } \\
\text { osiagnięć naukowo-badaw- } \\
\text { czych, } \\
\text { - niestabilność sceny poli- } \\
\text { tycznej, prowadząca często } \\
\text { do braku ciagłości i przewi- } \\
\text { dywalności w prowadzonej } \\
\text { polityce gospodarczej. }\end{array}$ & $\begin{array}{l}\text { - stopień zacofania technologicznego } \\
\text { i technicznego, } \\
\text { - możliwości w zakresie samodzielnego } \\
\text { prowadzenia prac badawczo-rozwojo- } \\
\text { wych i wdrażania innowacji (technolo- } \\
\text { gicznych i produktowych), } \\
\text { - stopień zadłużenia i dostępności do } \\
\text { źródeł zasilania finansowego (w tym } \\
\text { zewnętrznego), } \\
\text { - charakter powiązań rynkowych z oto- } \\
\text { czeniem (w szczególności w zakresie } \\
\text { zbytu i kierunków zaopatrzenia), } \\
\text { - ukształtowana kultura pracy, } \\
\text { - postawy pracowników wobec zmian, } \\
\text { - stopień ,uzwiązkowienia” załogi, } \\
\text { - jakość zarządzania i przygotowanie kie- } \\
\text { rownictwa do wdrażania procesu } \\
\text { restrukturyzacji, } \\
\text { - wielkość, wartość i charakter majątku } \\
\text { pozaprodukcyjnego, szczególnie ze sfe- } \\
\text { ry tzw. otoczki socjalnej (szkoły przy- } \\
\text { zakładowe, żłobki, przedszkola, ośrodki } \\
\text { wypoczynkowe itp.), } \\
\text { - wybrana forma prywatyzacji (lub brak } \\
\text { prywatyzacji). }\end{array}$ \\
\hline
\end{tabular}

Źródło: Opracowanie własne

\section{PoDATNOŚĆ PRZEDSIĘBIORSTW NA PROCESY ADAPTACYJNE}

\section{DO NOWYCH WARUNKÓW GOSPODARCZYCH}

Jak wykazują dotychczasowe badania, prowadzone w skali ogólnopolskiej w ośrodku toruńskim pod kierunkiem S. Sudoła (Sudoł, Karaszewski 1996; Sudoł 1996, 1997; Sudoł, Matuszak 2002), ośrodku warszawskim pod kierunkiem E. Mączyńskiej (2001) oraz innych autorów w ośrodkach akademickich kraju (m.in. Białasiewicz, Buczkowski 1996; Czapliński 2000, 2002, 2003; Domański 2001; Jażewicz, Rydz 1994, Hamrol, Stróżak 1998; Kurek 1996, Stępień 2001, Stryjakiewicz 1999, Tkocz 2001) przebieg procesu restrukturyzacji jest szczególnie uzależniony od sytuacji wewnętrznej przedsiębiorstw u progu restrukturyzacji, co warunkowało ich podatność na wdrożenie procesu restrukturyzacji. W pracy badawczej nad funkcjonowaniem przedsiębiorstw warto więc zwrócić szczególną uwagę na zróżnicowanie sytuacji wewnętrznej, w jakiej znalazły się przedsiębiorstwa na początku transformacji gospodarczej².

${ }^{2}$ Uwarunkowania zewnętrzne międzynarodowe transformacji przedsiębiorstw zostały omówione w innej pracy autora (Rachwał 2003), były także szeroko podejmowane w literaturze (por. Gierszewska, 
W świetle analizy literatury przedmiotu dotyczącej przebiegu procesu restrukturyzacji oraz badań autora prowadzonych w przedsiębiorstwach należy stwierdzić, że do grupy podstawowych czynników wewnętrznych stanowiących o podatności przedsiębiorstw na procesy restrukturyzacji należy profil działalności przemysłowej. W trudniejszej sytuacji znajdowały się na początku lat 90. przedsiębiorstwa działające w branżach wymagających ogromnych nakładów finansowych na restrukturyzację technologiczną, takich jak hutnictwo, przemysł elektroniczny bądź elektromaszynowy. Dobrym przykładem tego zjawiska są analizy trudności w zakresie restrukturyzacji, jakie wystąpiły w Fabryce Samochodów Ciężarowych „Star”, przeprowadzone przez W. Wypchło (1994) oraz w Fabryce Ciąników „Ursus”, przedstawione przez P. Krawczyka (1996). Specyficznymi warunkami objęty był także przemysł zbrojeniowy (w dużej mierze uzależniony od zamówień rządowych) oraz sektory „schyłkowe”, do których należy wydobycie i przetwórstwo siarki czy górnictwo węgla kamiennego. Powodowało to konieczność pomocy państwa w restrukturyzacji tych przedsiębiorstw, ale programy te - szczególnie w odniesieniu do górnictwa węgla kamiennego i hutnictwa (Tkocz 2001, Makieła 2002) - nie przynosiły zadowalających rezultatów.

Kolejnym istotnym czynnikiem warunkującym zdolność adaptacyjną przedsiębiorstw jest wielkość przedsiębiorstwa. Powszechnie przyjmuje się (Sudoł, Karaszewski 1996; Mączyńska 2001, Misztal 1994), że im mniejsze przedsiębiorstwo, tym łatwiej i szybciej można wdrożyć w nim proces restrukturyzacyjny i tym łatwiej przystosowuje się do niekorzystnych warunków otoczenia. Szczególne problemy występują w przypadku przedsiębiorstw bardzo dużych, nazywanych w literaturze najczęściej ,gigantami” (Misztal 1994) czy „dinozaurami” (Koźmiński 1998). Jak wskazuje A. Koźmiński (1998), przedsiębiorstwa te, działające głównie w przemyśle ciężkim i maszynowym, były tworzone w czasach gospodarki nakazowo-rozdzielczej jako silne jednostki polityczne, o dużym znaczeniu dla gospodarki państwa, z dużymi i wpływowymi organizacjami partyjnymi i związkowymi. Nowa sytuacja gospodarcza wytworzyła dużą niepewność i silne emocje wśród załogi w związku z wyraźnie zagrożoną pozycją tego typu przedsiębiorstw w procesie transformacji gospodarczej. W przedsiębiorstwach tych najsilniej zaznaczyły się mankamenty w strukturze zarządzania, polegające na zbyt dużym wpływie tzw. rad pracowniczych w procesie zarządzania. Nawet jeśli przedsiębiorstwo zostało przekształcone w spółkę akcyjną, i tym samym instytucja rad pracowniczych formalnie została wyeliminowana, to wystarczająco komplikowały proces zarządzania dwa-trzy silne związki zawodowe, konkurujące ze sobą na poziomie przedsiębiorstwa. W efekcie tworzyły się specyficzne postawy roszczeniowe i naciski polityczne na rozwiązanie problemu restrukturyzacji przy pomocy środków budżetu państwa oraz opór pracowników przed działaniami restrukturyzacyjnymi. Na negatywny wpływ zbytnio rozwiniętych związków zawodowych, partii politycznych, lobby i innych grup nacisku, w tym nieformalnych grup interesów, wywodzących się z czasów komunistycznych, na proces adaptacji przedsiębiorstw zwracają uwagę T. Stryjakiewicz (1999) oraz J. Filipczuk, P. Soroka i T. Wach (1998).

Warto podkreślić, że wspomniane poczucie zagrożenia i opór pracowników wobec zmian nie dotyczy tylko bardzo dużych, ale także innych, mniejszych przedsiębiorstw. Opór ten wynika - zdaniem Z. Sapijaszki (1997) - przede wszystkim z:

Wawrzyniak 2001, Godziszewski 2001, Liberska 2002, Zioło 2003, Zorska 1998, Żukrowska 2001), podobnie jak zewnętrzne uwarunkowania krajowe (por. Belka 2001, Czerwieniec 1997, Kołodko 1999, Koźmiński 1998, Lipowski 1997, Rosati 1998, Stępień 2001, Wojtyna 1994). 
- obawy przed utratą dotychczasowej pozycji w przedsiębiorstwie (zakresu władzy, swobody podejmowania decyzji, dostępu do zasobów, prestiżu i in.), w konsekwencji czego osoby zagrożone taką utratą mają na względzie tylko swój własny interes;

- niezrozumienia przyczyn, sensu i spodziewanych konsekwencji podejmowanej restrukturyzacji oraz braku zaufania pracowników do inicjatora zmian;

- rozbieżności w ocenie sytuacji przedsiębiorstwa, wynikającej najczęściej z braku dostępu przez ogół pracowników do informacji, które posiadają inicjatorzy restrukturyzacji;

- małej tolerancji dla zmian, wywołanej obawą przed niemożnością dostosowania własnych umiejętności do nowej sytuacji (wymogów).

Dlatego jednym z głównych czynników decydujących o powodzeniu procesu restrukturyzacji jest czynnik ludzki. To ludzie zatrudnieni w przedsiębiorstwie są realizatorami wszelkich zmian, stąd tak duże znaczenie mają ich dążenia, postawy i cechy: wykształcenie, zdolności przewidywania, umiejętności organizatorskie, przedsiębiorczość, kreatywność, zdolność wchłaniania innowacji. Jak wskazują dotychczasowe badania (Mączyńska 2001; Sudoł, Karaszewski 1996), najczęstszymi inicjatorami zmian byli członkowie kadry zarządzającej oraz rad pracowniczych przedsiębiorstw państwowych, natomiast wśród pozostałych osób, głównie pracowników najniższego szczebla, zaobserwowano niechęć do wszelkich działań restrukturyzacyjnych. Podejmując problematykę badawczą transformacji przedsiębiorstw przemysłowych należy więc szczególną uwagę poświęcić na uwarunkowania wynikające z jakości kapitału ludzkiego i postaw pracowników. Szczególna rola w procesie zmian przypada kadrze kierowniczej, w szczególności kadrze najwyższego szczebla, która jest odpowiedzialna za zarządzanie przedsiębiorstwem i tym samym za wdrażanie procesu restrukturyzacji. Jak wskazuje B. Stępień (2001), w pierwszej fazie procesu restrukturyzacji występowały trudności wynikające z negatywnych przyzwyczajeń kierownictwa przedsiębiorstw, których głównym zadaniem w poprzednim systemie było dbanie o wykonanie planów i zabieganie o jak największe środki na jego realizację, oraz z niewiedzy z zakresu zarządzania procesem restrukturyzacji. Stąd konieczne było opanowanie przez kierownictwo podstawowych funkcji zarządzania tym procesem, tj. planowania, organizowania, motywowania i informowania oraz kontrolowania. Na postawy kierownictwa przedsiębiorstw w pierwszych latach transformacji szczególną uwagę zwraca także S. Sudoł (1996). Analizując pierwszy okres transformacji (do 1992 r.) wyróżnił on trzy zasadnicze grupy przedsiębiorstw w zależności od ich postaw wobec nowego systemu ekonomicznego: 1) przedsiębiorstwa „maruderzy”, które z opóźnieniem i w bardzo małym stopniu podjęły działania przystosowawcze; 2) przedsiębiorstwa „środka”, które z trudem przełamywały swoją inercję; 3) przedsiębiorstwa „liderzy", które potrafiły wykorzystać zmiany w otoczeniu jako swoją szansę rozwojową (Sudoł 1997; Sudoł, Karaszewski 1996). Największe sukcesy restrukturyzacyjne osiągnęły przedsiębiorstwa z trzeciej grupy.

Oprócz wspomnianego wyżej czynnika wielkości zatrudnienia i postaw pracowników do procesów zmian istotne znaczenie miał stopień przerostu zatrudnienia w stosunku do potrzeb (wielkości produkcji), objawiający się niską wydajnością pracy. Należy przyjąć, że największe trudności w rozpoczęciu restrukturyzacji miały te przedsiębiorstwa, które musiały uporać się z problemem niskiej wydajności pracy i związanych z tym radykalnych redukcji zatrudnienia. Podobny problem wystąił z przerostem majątku trwałego, który jeśli był nieatrakcyjny pod względem wykorzystania w produkcji - stanowił poważny balast przedsiębiorstwa. W uprzywilejowanej sytuacji były przedsiębiorstwa położone w atrakcyj- 
nych częściach dużych miast, które nie miały dużych problemów z dzierżawą lub sprzedażą terenów i budynków czy wynajmem zbędnej powierzchni biurowej i magazynowej. Szerzej problematyka ta została przedstawiona na przykładzie terenów poprzemysłowych Służewca Przemysłowego przez A. Rutkowską (1998, 2000). Balastem była także infrastruktura służąca funkcjom socjalnym, w tym szkoły, żłobki, ośrodki zdrowia czy nawet ośrodki wypoczynkowe, które bardzo często ze względu na swoją wielkość i stopień zużycia nie były atrakcyjne dla potencjalnych nabywców. Należy podkreślić, że ze względu na olbrzymią wartość majątku trwałego występują ogromne trudności z prywatyzacją przedsiębiorstw, posiadających ogromny, w znacznej mierze zużyty majątek. Krajowi przedsiębiorcy prywatni nie posiadają odpowiednich środków finansowych, a zagraniczni inwestorzy powstrzymują się przed tak dużymi, ryzykownymi inwestycjami. Tego typu trudności prywatyzacyjne przemysłu zaznaczyły się szczególnie na obszarze GOP (Tkocz 1994, 1996).

Przeprowadzone badania oraz analiza literatury przedmiotu pozwala wskazać, że kolejnym ważnym czynnikiem wpływającym na podatność przedsiębiorstwa na procesy restrukturyzacyjne jest jego struktura organizacyjna. Stosunkowo najlepsza sytuacja była w przedsiębiorstwach, które mogły w miarę samodzielnie decydować o wyborze dostawców i które same prowadziły zbyt towarów. Przedsiębiorstwa, które miały bezpośredni kontakt z odbiorcami były w uprzywilejowanej sytuacji, gdyż ich strategia działania i struktura organizacyjna zorientowana produkcyjnie (charakterystyczna dla wszystkich przedsiębiorstw w gospodarce centralnie sterowanej) nabierała cech orientacji rynkowej czy wręcz marketingowej, jeśli przedsiębiorstwo samodzielnie prowadziło sprzedaż na rynkach zagranicznych. Bezpośrednie kontakty z odbiorcami były źródłem informacji zwrotnej, która powodowała, chociażby w minimalnym stopniu, modernizację asortymentu produkcji pod kątem oczekiwań odbiorcy. Natomiast zupełnie ,upośledzone” były przedsiębiorstwa (najczęściej ,giganty”), które nie odpowiadając za zbyt towarów, skupiały się wyłącznie na produkcji na zaplanowanym poziomie. W dobie całkowitej samodzielności przedsiębiorstwa te musiały tworzyć zupełnie nowe działy i rozpocząć działalność w tych ważnych obszarach niemal bez doświadczenia. Szybko traciły także swoje tradycyjne rynki, przede wszystkim z byłego obszaru RWPG (Koźmiński 1998). Odcięcie od dotychczasowych kanałów dystrybucji, konieczność budowy własnych więzi dystrybucyjnych od podstaw była dla nich wyjątkowo trudna. O zdolności adaptacyjnej do nowych warunków gospodarowania w znacznym stopniu decydują więc powiązania przedsiębiorstwa $z$ otoczeniem, co potwierdzają m.in. badania prowadzone pod kierunkiem S. Sudoła (Sudoł, Karaszewski 1996) oraz T. Stryjakiewicza (1999) i B. Stępień (2001) .

Analizując wpływ więzi przedsiębiorstwa na zdolności adaptacyjne, należy podkreślić wagę charakteru podpisanych kontraktów długoterminowych. W uprzywilejowanej sytuacji były przedsiębiorstwa, które przez pierwsze lata transformacji mogły realizować rentowne zamówienia i stopniowo przestawiać swoją produkcję pod kątem nowych potrzeb (Sudoł, Karaszewski 1996). Z drugiej strony mogło to być jednak powodem niewdrażania procesu restrukturyzacji, gdyż ze względu na ustabilizowaną pozycję kadra kierownicza nie zauważała potrzeby zmian, co w takim przypadku stało się przyczyną jeszcze większych trudności restrukturyzacyjnych w latach późniejszych.

Odmienna pozycja „wyjściowa” przedsiębiorstw wynikała także ze stopnia zacofania technologicznego i zużycia parku maszynowego. W najlepszej sytuacji były przedsiębior-

${ }^{3} \mathrm{O}$ przestrzennych powiązaniach przedsiębiorstw przemysłowych w zakresie zaopatrzenia i zbytu szerzej w innej pracy autora (Rachwał 2007). 
stwa wybudowane lub zmodernizowane pod koniec lat 70. i w latach 80., chociaż w przypadku niektórych sektorów (jak np. przemysłu elektronicznego), nawet inwestycje poczynione w II poł. lat 80 . okazały się niewystarczające, ze względu na stopień ich nowoczesności w stosunku do konkurencji zagranicznej. Jak wskazują badania prowadzone pod kierunkiem S. Sudoła (Sudoł, Karaszewski 1996), rozpoczęte inwestycje w latach gospodarki nakazowo-rozdzielczej, a niezakończone przed rozpoczęciem zmian systemowych stały się kolejnym, ogromnym balastem dla przedsiębiorstw. Większość z nich nie była w stanie kontynuować rozpoczętych inwestycji, które wcześniej były w dużej mierze finansowane przez państwo. $\mathrm{Z}$ drugiej strony, jeśli inwestycja była bardzo zaawansowana, podejmowano decyzję o jej kontynuacji, co wiązało się z zaciągnięciem drogich kredytów i nie zawsze prowadziło do uzyskania przewagi konkurencyjnej przedsiębiorstwa w nowych warunkach, gdyż „nowa” inwestycja najczęściej była już „na starcie” przestarzała technologicznie.

Z działalnością inwestycyjną wiąże się stopień zadłużenia przedsiębiorstw, które część swojej działalności inwestycyjnej pokrywały z kredytów. Niemal z dnia na dzień, w wyniku zastosowanej przez L. Balcerowicza „terapii szokowej”, zostały one postawione w obliczu gwałtownie rosnącego oprocentowania. Zdaniem B. Stępień (2001), sytuacja taka spowodowała gwałtowny wzrost kosztów finansowych, często akumulację nie spłacanych odsetek i szybkie pogarszanie się kondycji finansowej przedsiębiorstw, które stawały się niezdolne do normalnego funkcjonowania. Można więc przyjąć, że w korzystniejszej sytuacji były przedsiębiorstwa, które pod koniec lat 80 . nie zaciągały wysokich - w stosunku do możliwości płatniczych - kredytów.

\section{ŹRÓDŁA ZASILANIA FINANSOWEGO PROCESÓW RESTRUKTURYZACJI PRZEDSIĘBIORSTW}

Należy zwrócić uwagę, że problem zagadnień finansowych w procesie restrukturyzacji należy rozpatrywać nie tylko w aspekcie restrukturyzacji finansów (odbudowy finansów), ale także finansowania procesu restrukturyzacji (Kowalczuk-Jakubowska, Malewicz 1995). Jak wskazują Autorki, restrukturyzacja finansów dotyczy przedsiębiorstw będących w niekorzystnej sytuacji finansowej (a więc większości przedsiębiorstw u progu transformacji), jej celem jest przede wszystkim uzyskanie płynności finansowej, w tym zdolności do obsługi kredytów i w przyszłości kreowania zysków. Obejmuje ona szereg działań związanych z majątkiem trwałym i siłą roboczą, a także zarządzaniem finansami. W pierwszej kolejności działania te powinny zmierzać - zdaniem Autorek - w kierunku ograniczenia wydatków, tj. wstrzymania zatrudnienia nowych pracowników, zamrożenia płac, ograniczenia kosztów delegacji i zdyscyplinowania wydatków w każdej komórce organizacyjnej, anulowania nierentownych zamówień. Ograniczeniom wydatków powinna towarzyszyć aktywizacja źródeł pozyskania gotówki, obejmująca sprzedaż lub dzierżawę zbędnych aktywów (grunty, środki trwałe, zapasy, papiery wartościowe itd.), inkaso zaległych należności lub sprzedaż długów, wykorzystanie wszelkich ulg, dotacji, bezzwrotnych pomocy i kredytów oraz negocjacje $\mathrm{z}$ wierzycielami w celu redukcji zadłużenia lub ustalenia nowych warunków jego spłaty. Restrukturyzacja finansów jest w zasadzie warunkiem istnienia przedsiębiorstwa (w przypadku niepowodzenia wierzyciele będą zmuszeni wnioskować o ogłoszenie upadłości), a więc podstawą powodzenia całego procesu jego restrukturyzacji. 
Ponieważ proces restrukturyzacji obejmuje reorganizację całego przedsiębiorstwa i kosztowną modernizację majątku produkcyjnego, wymaga dużych nakładów inwestycyjnych i mimo podjętych działań na rzecz ograniczenia wydatków generuje dodatkowe koszty. Przedsiębiorstwo stoi więc w obliczu konieczności znalezienia źródeł finansowania procesu restrukturyzacji. Jest to kolejny czynnik różnicujący zdolności adaptacyjne przedsiębiorstw. Za H.-D. Torspeckenem (1993) źródła finansowania przedsiębiorstw można podzielić na dwie grupy: wewnętrzne i zewnętrzne. Finansowanie wewnętrzne występuje w dwóch formach: samofinansowania (nazywanego „tezauryzacją zysku”) i wewnętrznego finansowania obcego - poprzez tworzenie rezerw na tzw. niepewne zobowiązania w przyszłości. Formy finansowania wewnętrznego są, zdaniem Autora, bardziej korzystne dla przedsiębiorstwa (w porównaniu z finansowaniem zewnętrznym), ale - jak wskazują dotychczasowe badania (Sudoł, Karaszewski 1996; Mączyńska 2001) - w restrukturyzowanych przedsiębiorstwach występują bardzo rzadko, gdyż z reguły firmy te mają niską rentowność i nie wypracowują zysku lub w niezadowalającej wysokości. Ze względu na naturalne ograniczenia wewnętrznego finansowania procesu restrukturyzacji szczególnego znaczenia nabierają zewnętrzne źródła finansowania w dwóch zasadniczych formach: finansowania obcego (za pomocą kredytów) oraz finansowania poprzez udziały. Trzecią grupę stanowią formy mieszane. Przeprowadzone badania oraz literatura przedmiotu wskazuje, że zewnętrzne finansowanie obce $\mathrm{w}$ postaci kredytowania przedsiębiorstw w warunkach polskich napotyka na szereg barier. Jedną z nich jest słabość niebankowych podmiotów udzielających krótkoterminowych kredytów, głównie odbiorców i dostawców, czyli innych przedsiębiorstw, które najczęściej również borykają się z problemami płynności finansowej. Jakkolwiek duże znaczenie dla bieżącej działalności przedsiębiorstwa może mieć ta forma kredytowania, dla procesu restrukturyzacji, w tym realizacji programów inwestycyjnych, największe znaczenie mają długoterminowe kredyty bankowe. Jak wskazuje M. Zawadzki (2001), podstawową barierą dla restrukturyzowanych przedsiębiorstw w ich pozyskaniu była - szczególnie w pierwszej dekadzie transformacji - cena. W latach transformacji gospodarczej w Polsce kredyt ten był ze względu na wysokie oprocentowanie zbyt drogi, wymagał od przedsiębiorstw realizacji przedsięwzięć o wyższej rentowności, co w niektórych branżach było wręcz niemożliwe. Bariera ta wynikała w dużej mierze $\mathrm{z}$ polityki finansowej państwa, ale także ze słabości systemu bankowego w Polsce i stosunkowo małej konkurencji wśród banków, które wolą udzielać kredytów przedsiębiorstwom silnym ekonomicznie niż angażować się w ryzykowne procesy restrukturyzacji (szczególnie naprawczej) przedsiębiorstw. Zdaniem K. Mościbrodzkiej (2000) wynika to także z uniwersalnego charakteru systemu bankowego w Polsce, który powoduje, że zakres działania tych uniwersalnych banków nie pozwala na działalność o wysokim stopniu ryzyka. Z założenia banki te muszą prowadzić bezpieczną politykę (wynika to z przepisów prawa bankowego i norm narzuconych przez bank centralny). Brak wyspecjalizowanych banków inwestycyjnych jest więc w warunkach polskich istotną barierą w dostarczaniu środków na działania restrukturyzacyjne. Trudności w kredytowaniu działalności inwestycyjnej wynikają także z faktu, że banki nie potrafią ocenić skomplikowanych przedsięwzięć inwestycyjnych z powodu braku wyspecjalizowanych doradców w dziedzinie kredytowania inwestycji (Kotowicz-Jawor 1997). W ostatnich latach obserwuje się także problem związany z przejęciem sektora bankowego przez kapitał zagraniczny, który w swoich decyzjach o przyznaniu wysokich kredytów kieruje się często interesem przedsiębiorstw należących do swojej własnej sieci kapitałowej lub w inny sposób powiązanych z bankiem, co - jak wskazuje praktyka - w wielu przypadkach ogranicza dostęp do dużych kredytów dla polskich przedsiębiorstw. 
Drugą, podstawową formą finansowania zewnętrznego, jak wskazują badania, często najbardziej dostępną w pierwszym okresie transformacji dla przedsiębiorstw o dobrej kondycji ekonomicznej, jest finansowanie poprzez udziały. Ta forma finansowania istotnie wpływa na struktury organizacyjne przedsiębiorstwa, gdyż wiąże się ze zmianami własnościowymi. Oczywiście, inwestor dający kapitał, przejmuje udział w zarządzaniu przedsiębiorstwem, w wartości jego majątku trwałego i wypracowanym zysku. Dla przyjmującego (przedsiębiorstwa restrukturyzowanego) oznacza to więc dzielenie się prowadzeniem przedsiębiorstwa i zyskami, ale także korzyści (w porównaniu z kredytowaniem) w postaci braku obowiązku spłacania stałych odsetek, rozkładu ryzyka, długoterminowej możliwości wykorzystania tego kapitału czy zwiększenia kapitału własnego i wiarygodności kredytowej. Jak wskazują badania własne i prowadzone przez innych autorów (Stryjakiewicz 1999; Domański 2001; Sudoł, Karaszewski 1996), wpływ pozyskanego kapitału na proces restrukturyzacji uzależniony jest głównie od charakteru inwestora (branżowy/finansowy), jego zasobów kapitałowych, doświadczenia, zasięgu działania oraz znaczenia inwestycji w jego globalnej strategii. Najbardziej pożądane są bezpośrednie inwestycje branżowych inwestorów strategicznych, które są gwarancją dopływu znaczącego i długoterminowego kapitału oraz - co nie występuje w przypadku inwestycji pośrednich poprzez inwestorów finansowych i drobnych inwestorów indywidualnych - dopływu tzw. know-how. Ze względu na ograniczone możliwości finansowe inwestorów krajowych rolę inwestora strategicznego często przyjmują inwestorzy zagraniczni, którzy dysponują znacznie większymi możliwościami finansowymi, tj. z reguły mają łatwiejszy dostęp do bankowych i pozabankowych źródeł finansowania zewnętrznego (w tym zdecydowanie tańszych kredytów krótko- i długoterminowych).

Analizując problematykę źródeł finansowania procesów restrukturyzacyjnych należy zgodzić się z opinią wielu autorów, że w praktyce restrukturyzowane przedsiębiorstwo w warunkach polskich nie miało w pierwszych latach transformacji wyboru między wewnętrznymi a zewnętrznymi źródłami finansowania. W warunkach transformacji systemowej większość podmiotów nie wypracowuje nadwyżki finansowej, stąd ich uzależnienie od finansowania zewnętrznego (w tym kapitału zagranicznego). Potwierdzają to badania prowadzone pod kierunkiem E. Mączyńskiej (2001), z których wynika, że najwyższą skłonność do inwestowania (wg wskaźnika wartości inwestycji na 1 zatrudnionego) miały przedsiębiorstwa z udziałem inwestora zagranicznego, znacznie mniejszą spółki z kapitałem krajowym, JSSP i spółki giełdowe, najniższą zaś spółki pracownicze i NFI. Wpływa to na zróżnicowanie zdolności adaptacyjnych przedsiębiorstw w zależności od wybranej formy prywatyzacji i wynikającej z niej struktury własnościowej.

\section{KWESTIONARIUSZ DO BADAŃ FUNKCJONOWANIA PRZEDSIĘBIORSTWA}

Podjęcie problematyki badawczej nad funkcjonowaniem przedsiębiorstw przemysłowych wymaga zastosowania odpowiednich metod badań. Jedną z nich, na którą warto zwrócić szczególną uwagę, jest metoda kwestionariusza, mająca powszechne zastosowanie w geografii przemysłu. Kwestionariusz jest nieodłączną pomocą w badaniach przemysłu, szczególnie w sytuacji, gdy zdecydowana większość aspektów funkcjonowania przedsiębiorstw jest pomijana w oficjalnej statystyce. Zastosowany w pracy badawczej kwestionariusz oparto na stosowanym szczególnie w ośrodku krakowskim kwestionariuszu L. Pakuły (1967), stwo- 
rzonym dla badań funkcjonowania przedsiębiorstw w ramach gospodarki centralnie sterowanej i zmodyfikowanym później przez M. Troca (1991a,b) oraz kwestionariuszu R. Rileya i S. Pączki (Pączka 1994), funkcjonującym w ośrodku łódzkim4.

W dotychczasowych pracach badawczych autora kwestionariusz został poddany weryfikacji. Kwestionariusz okazał się bardzo dobrym narzędziem pracy; w wyniku jego weryfikacji nasuwają się pewne sugestie o charakterze metodycznym, na które warto zwrócić uwagę przy omówieniu poszczególnych grup zagadnień podejmowanej problematyki badawczej. Jego przydatność w badaniach empirycznych jest związana z przychylnością zarządów i dyrekcji firm pozwalających na ujawnienie interesujących badacza zagadnień. Dlatego zakres czasowy i merytoryczny oraz szczegółowość zebranych danych na podstawie kwestionariusza były bardzo zróżnicowane i nie należy zakładać, że w prowadzonych badaniach uda się uzyskać w pełni porównywalne dane z większej grupy przedsiębiorstw. Weryfikacja kwestionariusza pozwoliła także na opracowanie jego nowszej wersji, w większym stopniu uwzględniającej uwarunkowania związane z wpływem procesów globalizacji i integracji europejskiej, dostosowującej jego zakres zarówno do zmieniającej się sytuacji gospodarczej, jak i do realnych możliwości pozyskania danych (załącznik 1). Kwestionariusz może być podstawą do opracowania ankiet, które można stosować w przypadku, gdy przedsiębiorstwo odmawia pozwolenia na przeprowadzenie samodzielnych badań przez autora, a jedynie zgadza się odpowiedzieć na pytania ankiety.

Ponieważ proces zmian funkcjonowania przedsiębiorstwa ma charakter dynamiczny oraz ciągłym zmianom podlegają także warunki otoczenia, dlatego dane zbierane na podstawie kwestionariusza powinny obejmować co najmniej kilka przekrojów czasowych - lata funkcjonowania w ramach gospodarki centralnie sterowanej (koniec lat 80., najczęściej 1989 r.) jako punkt wyjściowy (czyli ustalenie sytuacji wewnętrznej, w jakiej znajdowało się przedsiębiorstwo u progu transformacji) i etap funkcjonowania po zmianie systemu gospodarowania (lata 90. oraz pierwszą dekadę XXI w.). Ze względu na fakt, że istotny wpływ na procesy restrukturyzacji w przedsiębiorstwie mógł mieć proces prywatyzacji i pojawienie się inwestora strategicznego (w szczególności zagranicznego) w okresie drugim warto starać się uchwycić dane wskazujące na wpływ zmian własnościowych na proces adaptacji przedsiębiorstw do nowych warunków gospodarowania (ryc. 1). Na funkcjonowanie przedsiębiorstw mogła mieć także silny wpływ akcesja Polski do UE, stąd wydaje się celowe zebranie danych w przekrojach czasowych bezpośrednio przed i po 2004 r. (np. 2005, 2006), chociaż w niektórych wypadkach potrzeba dłuższego okresu czasu, aby uchwycić wpływ integracji Polski z UE na zmiany funkcjonowania. W zależności od konkretnej sytuacji danego przedsiębiorstwa może być konieczne wyodrębnienie innych okresów i wyznaczenie takich przedziałów czasowych, które pozwolą na uchwycenie wpływu istotnego dla przedsiębiorstwa działania na jego funkcjonowanie. Przykładowo, takimi istotnymi momentami funkcjonowania przedsiębiorstwa może być „wejście” na giełdę papierów wartościowych (krajową lub zagraniczną), fuzja z innym dużym podmiotem, wydzielenie (podział) znacznej części przedsiębiorstwa, podjęcie decyzji o umiędzynarodowieniu działalności (w wyniku otwarcia zagranicznych oddziałów, filii czy znaczącej sieci przedstawicielstw handlowych). Istotne jest więc zidentyfikowanie w trakcie wywiadów w przedsiębiorstwach tych najważniejszych punktów zwrotnych w jego funkcjonowaniu.

\footnotetext{
${ }^{4}$ Kwestionariusz został szczegółowo omówiony we wcześniejszej pracy autora (Rachwał 2001).
} 


\begin{tabular}{|c|c|c|c|c|}
\hline Okres gospodarki centralnie sterowanej & \multicolumn{5}{|c|}{ Okres transformacji systemu gospodarowania } \\
\hline 1 & $2 \mathrm{a}$ & $2 \mathrm{~b}$ & $2 \mathrm{c}$ & $2 \mathrm{~d}$ \\
\hline & $1989 \mathrm{r}$. & prywatyzacja & $\begin{array}{c}\text { inwestor } \\
\text { strategiczny }\end{array}$ & $\begin{array}{c}\text { wejście PL do UE } \\
(2004 \mathrm{r} .)\end{array}$
\end{tabular}

Źródło: Opracowanie własne

Ryc. 1. Etapy funkcjonowania przedsiębiorstwa

\section{DOBÓR PRZEDSIĘBIORSTW DO BADAŃ}

Ważnym, wstępnym etapem prac badawczych przy podejmowaniu problematyki funkcjonowania przedsiębiorstw przemysłowych jest odpowiedni dobór przedsiębiorstw do badań, biorący pod uwagę kryteria położenia, wielkości, przynależności działowej i funkcji pełnionej w strukturze gospodarczej. Przy doborze przedsiębiorstw pomocne mogą być następujące kryteria:

- zróżnicowanie branżowe (działowe) przedsiębiorstw - szczególną uwagę warto zwrócić na te działy, których znaczenie w strukturze przemysłu w badanym regionie/kraju jest duże, lub postarać się tak dobrać przedsiębiorstwa, aby ich struktura działowa odpowiadała strukturze przemysłu badanego obszaru;

- wielkość potencjału przemysłowego - według kryteriów zgodnych z Ustawą o swobodzie działalności gospodarczej: mikro, małe, średnie bądź duże przedsiębiorstwa; w praktyce sektor przemysłowy jest reprezentowany głównie przez średnie i duże przedsiębiorstwa, stąd może wystąpić konieczność przyjęcia własnego kryterium wielkościowego w odniesieniu do bardzo dużych przedsiębiorstw;

- funkcje pełnione w strukturze gospodarczej - standardowe, komplementarne, regionalne, krajowe i międzynarodowe;

- położenie przestrzenne - główne ośrodki przemysłowe na badanym obszarze;

- forma organizacyjno-prawna i status spółki publicznej notowanej na giełdzie papierów wartościowych - chociaż zgodnie z Kodeksem Spółek Handlowych i Kodeksem Cywilnym możliwe jest prowadzenie działalności w formie 7 spółek: cywilnej, jawnej, partnerskiej, komandytowej, komandytowo-akcyjnej, z ograniczoną odpowiedzialnością i akcyjnej, nie licząc indywidualnej działalności gospodarczej, spółdzielczych i europejskich form prowadzenia działalności gospodarczej, to w praktyce przedsiębiorstwa przemysłowe funkcjonują głównie jako spółki kapitałowe, tj. z o.o. i akcyjne (których uwarunkowania prawne funkcjonowania są bardzo zbliżone) bądź przed komercjalizacją w postaci „starej” formy - przedsiębiorstwa państwowego; dużo większe znaczenie ma więc fakt, czy akcje spółki są dostępne w publicznym obrocie;

- zróżnicowanie form własności - ze względu na duży wpływ formy prywatyzacji na funkcjonowanie przedsiębiorstw należy wziąć pod uwagę przedsiębiorstwa państwowe (niesprywatyzowane), jednoosobowe spółki Skarbu Państwa (a więc przedsiębiorstwa własności państwowej jedynie skomercjalizowane) oraz przedsiębiorstwa funkcjonujące $\mathrm{w}$ formie różnego typu spółek:

- z dominującym udziałem Skarbu Państwa, 
- z udziałem kapitału zagranicznego (kontrolnym lub nie; przy rozróżnieniu inwestorów branżowych i finansowych),

- z dużym (dominującym) udziałem inwestorów finansowych,

- w których kontrolny pakiet akcji posiada inwestor branżowy,

- w których kontrolny pakiet akcji posiadają pracownicy (sprywatyzowane w formie tzw. akcjonariatu pracowniczego),

- z rozproszonym akcjonariatem pomiędzy drobnych akcjonariuszy (np. w wyniku prywatyzacji poprzez giełdę),

- funkcjonujące przez dłuższy czas okresu transformacji w ramach NFI (sprywatyzowane w Programie Powszechnej Prywatyzacji).

\section{ZAKRESY (OBSZARY) BADAŃ FUNKCJONOWANIA PRZEDSIĘBIORSTWA}

Po dokonaniu doboru próby badanych przedsiębiorstw przemysłowych można podjąć, na podstawie zebranego za pomocą kwestionariusza materiału empirycznego, analizę zmian zachowań w świetle różnych aspektów funkcjonowania przedsiębiorstwa. Do najistotniejszych obszarów funkcjonowania przedsiębiorstwa, które należałoby w pierwszej kolejności poddać analizie, należą zmiany wlasnościowe, w tym przede wszystkim odpowiedź na pytanie, w jakim zakresie proces restrukturyzacji był uzależniony od formy i czasu prywatyzacji przedsiębiorstwa. Innymi słowy, jak własność przedsiębiorstwa wpływa na proces zmian jego funkcjonowania. Przy analizie zmian własnościowych w przedsiębiorstwach należy zwrócić uwagę na różne, wymienione wyżej kategorie własnościowe przedsiębiorstw. Przyjmowany bardzo często w analizach podział na 2 grupy: przedsiębiorstwa państwowe i przedsiębiorstwa sprywatyzowane, wydaje się daleko niewystarczający. Grupy te są bowiem bardzo niejednorodne, szczególnie te zaliczane do własności prywatnej. Nie należy także mechanicznie oddzielać przedsiębiorstw państwowych, funkcjonujących jeszcze na podstawie Ustawy o przedsiębiorstwach państwowych z $1981 \mathrm{r}$. od reszty przedsiębiorstw funkcjonujących na zasadach Kodeksu Spółek Handlowych. Należy się zastanowić, czy do grupy przedsiębiorstw państwowych (w sensie własności, a nie formy organizacyjno-prawnej), nie należałoby zaliczyć przedsiębiorstw skomercjalizowanych, a więc przekształconych tylko w jednoosobową spółkę skarbu państwa, niecelowe wydaje się bowiem łączenie ich z przedsiębiorstwami sprywatyzowanymi sensu stricte, gdyż nadal właścicielem ich jest państwo i ten fakt wydaje się mieć większe znaczenie niż sama forma prawna.

Od formy prywatyzacji (bądź jej braku) i wielkości przedsiębiorstwa silnie uzależnione są zmiany struktur organizacyjnych przedsiębiorstw. W toku prowadzonych badań stwierdzono, że najbardziej znaczące zmiany struktur organizacyjnych zaszły w przedsiębiorstwach sprywatyzowanych, przy czym największe wystąpiły w przedsiębiorstwach przejętych przez inwestorów zagranicznych, co związane było głównie z dostosowaniem tej struktury do standardów koncernu. Także bardzo duże (zatrudniające kilka tysięcy osób) przedsiębiorstwa niesprywatyzowane lub sprywatyzowane bez udziału kapitału zagranicznego przeszły gruntowne zmiany struktury organizacyjnej, związane z wydzielaniem działów przedsiębiorstw w postaci spółek-córek i tworzeniem rozbudowanych grup kapitałowych. Takie przekształcenia struktury organizacyjnej nie zawsze dawały pozytywne rezultaty i w wielu z nich spowodowały konieczność częściowej, ponownej koncentracji prowadzonej 
działalności. Stosunkowo niewielkie zmiany struktur organizacyjnych zachodzą w przedsiębiorstwach niesprywatyzowanych mniejszej wielkości, gdyż ograniczają się one jedynie do wzmocnienia działów związanych ze sprzedażą i bieżącego dostosowywania pozostałych komórek do zmieniającego się profilu działalności i zmiany wielkości zatrudnienia. Wskazuje to na konieczność wyróżnienia wśród przedsiębiorstw dużych (powyżej 250 zatrudnionych) co najmniej jednej, dodatkowej kategorii: przedsiębiorstw bardzo dużych. Tradycyjny podział (wynikający z Ustawy o swobodzie działalności gospodarczej, stosowany najczęściej w statystyce publicznej i przy programach pomocowych UE) na przedsiębiorstwa mikro-, małe, średnie i duże jest bardziej przydatny do analiz funkcjonowania sektora MŚP oraz działalności firm usługowych. Stwierdzono jednak jego małą przydatność do analiz funkcjonowania przedsiębiorstw przemysłowych, gdyż zdecydowana większość z nich, ze względu na specyficzny charakter działalności, należy do kategorii przedsiębiorstw dużych (powyżej 250 zatrudnionych). W pracy badawczej stwierdzono zaś bardzo duże różnice w zakresie zmian funkcjonowania przedsiębiorstw dużych, zatrudniających np. 300-1000 osób, i przedsiębiorstw bardzo dużych, ,gigantów” mających kilka lub kilkanaście tysięcy zatrudnionych. W pracy badawczej autora wyróżniono więc kategorię przedsiębiorstw bardzo dużych, mających pod koniec okresu badawczego powyżej 3000 zatrudnionych. Warto zastanowić się nad wprowadzeniem dodatkowej kategorii wielkościowej w doborze przedsiębiorstw do badań i późniejszej analizie. Takie dodatkowe kategorie w analizie procesów transformacji przedsiębiorstw przemysłowych stosuje wielu autorów (por. Rydz 2007).

W ramach problematyki stosunków pracy istotny problem badawczy stanowią zmiany poziomu i struktur zatrudnienia, w tym zmiany na stanowiskach kierowniczych, szczególnie w przypadku przejęcia przedsiębiorstwa przez koncern zagraniczny. W badaniach prowadzonych przez autora wykazano, że podstawową cechą procesu restrukturyzacji była redukcja zatrudnienia przy równoczesnym podnoszeniu jakości kapitału ludzkiego w przedsiębiorstwach, dzięki rozbudowanemu systemowi szkoleń, podnoszących kwalifikacje pracowników. W przypadku przedsiębiorstw funkcjonujących przed 1989 rokiem nie należy się więc spodziewać podziału na dwie grupy charakteryzujące się spadkiem i wzrostem zatrudnienia. W większości wypadków konieczne więc będzie wyróżnienie różnych kategorii przedsiębiorstw w zależności od stopnia redukcji zatrudnienia. Ze względu na wielkość wskaźnika dynamiki zatrudnienia (obliczonego w sposób klasyczny, tj. przy założeniu, że rok początkowy to $100 \%$ ) w badanej grupie przedsiębiorstw wyróżniono 4 typy przedsiębiorstw:

I - o małym spadku zatrudnienia (wskaźnik dynamiki 60-80\%);

II - o umiarkowanym spadku zatrudnienia (wskaźnik dynamiki 40-60\%);

III - o dużym spadku zatrudnienia (wskaźnik dynamiki 20-40\%);

IV - o bardzo dużym spadku zatrudnienia (wskaźnik dynamiki 0-20\%).

Analizując literaturę przedmiotu i wnioski z badań innych autorów można dojść do wniosku, że przy przyjęciu co najmniej 10-letniego okresu badań wyróżnione kategorie mogą mieć charakter uniwersalny.

Należy jednak zwrócić uwagę, że tempo spadku zatrudnienia w badanym okresie może być zróżnicowane, mogą nawet wystąpić okresy niewielkiego wzrostu zatrudnienia. W pracy badawczej autora wykazano na przykład, że w przebiegu zmian poziomu zatrudnienia zaznaczała się prawidłowość, polegająca na wystąpieniu trzech faz redukcji zatrudnienia dwóch faz o dużym spadku zatrudnienia (1989-1992, 1998-2004) i jednej fazy względnej stabilizacji lub małego spadku zatrudnienia (1993-1997). Na zmiany poziomu zatrudnie- 
nia wpływ miało wiele czynników, m.in. moment prywatyzacji, wejście inwestora strategicznego, podział przedsiębiorstwa, zawarte umowy w momencie prywatyzacji itp. Dlatego w pracach badawczych nad funkcjonowaniem przedsiębiorstw przemysłowych cenne wydaje się zebranie pełnych, corocznych danych o zatrudnieniu, co pozwala na obliczenie indeksów dynamiki o podstawie łańcuchowej i uchwycenie prawidłowości w zakresie fluktuacji zmian zatrudnienia w całym badanym okresie. Dane z dwóch przekrojów czasowych (np. 1989 i 2007) i obliczony wskaźnik dynamiki o podstawie stałej dla roku początkowego nie pozwalają na pełne uchwycenie związków między zmianami poziomu zatrudnienia a strategicznymi zmianami w innych obszarach funkcjonowania przedsiębiorstwa.

Pewnym problemem przy badaniach poziomu zatrudnienia okazały się zmiany organizacyjne, polegające na wydzielaniu się części zakładów w postaci spółek-córek, podziałów i innych przekształceń formalnoprawnych. Dlatego analiza zmian zatrudnienia nie powinna ograniczać się tylko do zmian w spółce dominującej (spółce-matce), ale także w spółkachcórkach. Wymaga to dokładnej analizy zmian zatrudnienia w spółkach wydzielonych, tym bardziej że część z nich prowadzi działalność usługową i nie jest nawet w oficjalnych statystykach zaliczana do działalności przemysłowej. W oficjalnych statystykach i różnych listach rankingowych pojawia się bowiem zatrudnienie dla spółki-matki i spółek-córek łącznie lub osobno dla każdej spółki. Łączenie się formalne w grupy kapitałowe nie jest także dużym ułatwieniem dla badacza, gdyż wynika ono z przesłanek związanych z opodatkowaniem i niekoniecznie obrazuje charakter rzeczywistych powiązań sieciowych. Analiza zmian zatrudnienia wymaga więc opracowania metodologii postępowania w takich przypadkach, np. zaliczania zatrudnienia w spółkach zależnych, w których przedsiębiorstwo ma 100\% udziałów i które pracują tylko na jego rzecz do zatrudnienia przedsiębiorstwa ogółem. Czasem konieczne jest więc prześledzenie wszystkich przekształceń organizacyjno-prawnych od początku przyjętego okresu badawczego. Ze względu na trudności z tym związane część badaczy uznaje, że należy konsekwentnie brać pod uwagę tylko jednostkę podstawową (spółkę-matkę), trzeba pamiętać jednak, że nagłe spadki zatrudnienia mogą wynikać nie tyle z grupowych zwolnień pracowników, co z wyodrębnienia jakiejś jednostki w postaci osobnej, samobilansującej się spółki. W sytuacji, w której wiele przedsiębiorstw przekształca w taki sposób swoje poszczególne wydziały produkcyjne, nie zmieniając de facto istoty swojego działania, można mieć wątpliwości co do słuszności takiego podejścia.

Analizując zmiany w zatrudnieniu należy się również zastanowić, czy szacowanie tzw. efektów mnożnikowych w zakresie tworzenia nowych miejsc pracy nie powinno być integralną częścią badań zmian funkcjonowania przedsiębiorstw przemysłowych. Bardzo często w analizach dotyczących zatrudnienia zwraca się uwagę tylko na jego redukcję, pomijając kwestię tworzenia nowych miejsc pracy, ale w spółkach zależnych bądź przedsiębiorstwach współpracujących. Na istotę tego problemu zwrócił uwagę m.in. zespół badający wpływ GlaxoSmithKline Pharmaceuticals w Poznaniu na regionalny rynek pracy, pracujący pod kierunkiem T. Stryjakiewicza (2004), oraz K. Wiedermann (2006, 2007, 2008) badający efekty mnożnikowe rozwoju przemysłu motoryzacyjnego w województwie śląskim. Szacowanie efektów mnożnikowych jest utrudnione w sytuacji badań przedsiębiorstwa funkcjonującego już na rynku (ze względu na konieczność cofnięcia się do początków działalności lub przyjęcie pewnych założeń upraszczających), nie stanowi natomiast problemu analiza efektów mnożnikowych nowo powstających przedsiębiorstw, chociaż komplikacje pojawiają się przy próbie domknięcia lokalnego lub regionalnego badanego zjawiska ${ }^{5}$.

${ }^{5}$ Metodę szacowania efektów mnożnikowych przestawia K. Wiedermann w kolejnym artylule niniejszego tomu oraz niepublikowanej pracy (Wiedermann 2006). 
W analizie zmian funkcjonowania przedsiębiorstwa istotne znaczenie mają zmiany nie tylko poziomu, ale i struktur zatrudnienia. Do szczególnie ważnych struktur zatrudnienia w przedsiębiorstwie należy zaliczyć: stosunek pracowników zatrudnionych na stanowiskach robotniczych (produkcyjnych) do pracowników nierobotniczych (umysłowych), strukturę wykształcenia, płci, wieku i stażu pracy. Prowadzone badania w przedsiębiorstwach wykazały m.in.: wzrost udziału pracowników umysłowych (w stosunku do pracowników na stanowiskach robotniczych) oraz spadek udziału pracowników z wykształceniem podstawowym na rzecz pracowników z wykształceniem zasadniczym zawodowym i średnim (na stanowiskach robotniczych) oraz wzrost udziału pracowników z wykształceniem wyższym (na stanowiskach nierobotniczych). Należy zwrócić uwagę, że badania przemian struktur zatrudnienia były zawsze tradycyjnie prowadzone przez geografów przemysłu, dlatego ich znaczenie nie wymaga szerszego objaśnienia. Zastanawiający jest jedynie sens badań przemian struktur płci w kontekście analizy funkcjonowania przedsiębiorstwa. Zmiany takie poddano analizie w pracy badawczej, ale jest to problem rzadko ostatnio podejmowany na gruncie geografii przemysłu, a także nauk ekonomicznych, ze względu na mały wpływ na funkcjonowanie przedsiębiorstw. Są to badania bardziej interesujące osoby zajmujące się rynkiem pracy od strony aktywizacji zasobów pracy ze względu na płeć. Wynikami tych analiz mogą być więc zainteresowane organizacje społeczne walczące z dyskryminacją kobiet na rynku pracy (wyniki badań moga potwierdzać głoszone przez nich tezy, że w okresie transformacji w pierwszej kolejności miejsca pracy tracą kobiety, co jest formą dyskryminacji). Należałoby się zastanowić także nad badaniem problemu ,uzwiązkowienia” załogi. Zaproponowany kwestionariusz obejmuje tę problematykę, która wydaje się ważna w kontekście spostrzeżeń różnych autorów (m.in. T. Stryjakiewicza, 1999), że wysoki udział pracowników w związkach zawodowych może wpływać hamująco na proces zmian. Rzeczywistość badawcza okazała się jednak bardziej złożona. Po pierwsze, wystąpiły trudności w dostępie do danych, nie tyle o procentowym udziale pracowników w działalności związkowej, ile o ich stanowisku i zachowaniu w kluczowych momentach funkcjonowania firmy (często sprzeczne postawy i/lub przekazywane informacje, np. przeszkadzanie lub popieranie inwestora). Po drugie, prowadzący wywiad w tej sprawie może być traktowany nieco podejrzliwie, jako osoba próbująca zaburzyć stosunki kierownictwa z załogą.

Podejmowane badania stosunków pracy powinny obejmować także problematykę dojazdów do pracy (por. Herma 1966; Kitowski 1988, 1989). Należy zwrócić uwagę, że badania te są bardzo czasochłonne (przedsiębiorstwa generalnie nie prowadzą tego typu analiz, nie ma z reguły żadnych terytorialnych zestawień). Z punktu widzenia funkcjonowania przedsiębiorstw, które w obecnych czasach z reguły nie organizują i nie ponoszą kosztów dojazdu, miejsce zamieszkania pracowników ma marginalne znaczenie. Zastanawiający jest więc sens zbierania danych o dojazdach do pracy z punktu widzenia analizy zmian funkcjonowania samego przedsiębiorstwa. Wydaje się to jednak niezbędne w przypadku próby uchwycenia wpływu procesów transformacji przedsiębiorstw na kształtowanie się lokalnego czy regionalnego rynku pracy, co potwierdzają m.in. badania prowadzone pod kierunkiem T. Stryjakiewicza (2004).

Problematyka badawcza stosunków pracy powinna obejmować także przemiany jakościowe, polegające na przekwalifikowaniach pracowników oraz różnego rodzaju szkoleniach. Efekty tych działań bardzo często nie zostaną ujawnione w postaci zmian struktur wg wykształcenia, gdyż z reguły nie kończą się przyznaniem oficjalnego dyplomu, ze względu na pozaszkolną formę takiego dokształcania. W trakcie badań okazało się, że wiele firm pro- 
wadzi nie tylko „szkolenia twarde”, związane z produkcją w danym przedsiębiorstwie, ale także „szkolenia miękkie”, np. z zakresu komunikacji interpersonalnej, roli lidera w pracy zespołowej czy radzenia sobie ze stresem. Niektóre z przedsiębiorstw mogą organizować takie szkolenia dla odchodzących pracowników, co przyczynia się do przemian jakościowych na regionalnym czy lokalnym rynku pracy, a nie tylko w samym przedsiębiorstwie.

Jednym z ważnych warunków powodzenia procesu restrukturyzacji jest dostępność kapitału niezbędnego przede wszystkim do przeprowadzenia innowacji technologicznych, dlatego w pracy badawczej należy postawić problem źródeł zasilania finansowego procesu zmian, w szczególności należy zmierzać do określenia wpływu inwestycji kapitału zagranicznego na zmiany procesu technologii produkcji w przedsiębiorstwach. Należy zwrócić uwagę, że problematyka źródeł finansowania jest bardzo często podejmowana w analizach na gruncie nauk ekonomicznych, rzadziej geograficznych. A przecież od niej zależy szereg zmian: technologicznych, produktowych, zmian w zakresie zaopatrzenia i zbytu i wreszcie efekty ekonomiczne, które mogą decydować w ogóle o istnieniu przedsiębiorstwa.

Dlatego zdając sobie sprawę ze znaczenia dostępności do źródeł finansowania w kwestionariuszu uwzględniono szereg punktów dotyczących tej problematyki, w tym dwie zupełnie nowe - w porównaniu z poprzednimi kwestionariuszami L. Pakuły (1967) i M. Troca (1991a, 1991b) - grupy problemów dotyczące inwestora strategicznego. Przy analizie inwestycji kapitału zewnętrznego pojawiają się ważne kwestie. Pierwsza dotyczy rozróżnienia kwoty rzeczywistych inwestycji w środki produkcji, modernizację majątku trwałego, prace badawczo-rozwojowe, rozbudowę sieci sprzedaży itd., jednym słowem - w działalność przedsiębiorstwa, od inwestycji polegającej na sfinansowaniu zakupu akcji, np. od Skarbu Państwa oraz premii prywatyzacyjnych dla załogi lub odpraw dla zwalnianych pracowników. Ta druga forma inwestycji jest $\mathrm{z}$ reguły w oficjalnej statystyce zaliczana do wartości inwestycji ogółem, natomiast z punktu widzenia funkcjonowania przedsiębiorstwa nie ma ona praktycznie znaczenia, gdyż środki te nie trafiają na jego konto. Jednak w analizach ogólnych wpływu inwestycji na otoczenie kwoty wydatkowane na zakup akcji, czy udziałów bądź premie prywatyzacyjne (inwestycyjne) dla załogi należy wziąć pod uwagę korzyści dla finansów publicznych czy osobistych pracowników. Podobny problem występuje w przypadku ponownej, drugiej inwestycji, np. odkupieniu przedsiębiorstwa przez jeden koncern zagraniczny od drugiego. W przypadku inwestorów zagranicznych kwota ta jest zaliczana przez PAIZ i inne instytucje monitorujące napływ inwestycji zagranicznych do Polski do inwestycji zagranicznych ogółem, a z punktu widzenia przedsiębiorstwa są to często tylko przepływy finansowe między nowym a starym właścicielem. Wskazuje to na dużą wartość analiz opartych na pierwotnych danych empirycznych, zebranych $\mathrm{w}$ przedsiębiorstwach w stosunku do analiz opartych na danych wtórnych, z oficjalnych statystyk. Na marginesie należy dodać, że w ten sposób bardzo często może być sztucznie podwyższana oficjalna kwota napływu inwestycji zagranicznych do danego regionu czy kraju.

Dużą rolę odgrywają także analizy zmian technologicznych produkcji, bezpośrednio wpływające na możliwość przeprowadzenia zmian asortymentowych produkcji, których analiza z punktu widzenia konkurencyjności przedsiębiorstwa jest bardzo ważna - od innowacji technologicznych prowadzących do wzrostu konkurencyjności produktów zależy przecież w dużej mierze pozycja konkurencyjna przedsiębiorstwa na rynku krajowym i rynkach zagranicznych. W analizie zmian technologicznych pomocne mogą być nie tylko deklaratywne dane przedsiębiorstwa o wysokości inwestycji, ale także sprawozdania finansowe zawierające dane o zmianie wartości majątku i kosztach amortyzacji, co pozwala 
ocenić działalność inwestycyjną przedsiębiorstwa w majątek trwały. W świetle prowadzonych badań należy zwrócić uwagę, że bardzo często wstępne deklaracje inwestorów zagranicznych o wielkości planowanej inwestycji nie znajdują odzwierciedlenia w późniejszych sprawozdaniach finansowych bądź są przeznaczane nie na rzeczywiste inwestycje w majątek produkcyjny, ale na różnego typu wartości niematerialne, np. na opłaty licencyjne dla zagranicznej spółki-matki, analizy marketingowe czy nawet opłaty za możliwość korzystania z logo koncernu. Nawet w przypadku podpisania umowy określającej docelową wartość inwestycji w majątek produkcyjny przez inwestora korzystającego z przywilejów wynikających z położenia w specjalnych strefach ekonomicznych, kwoty te mogą być sztucznie zawyżane poprzez stosowanie między zagraniczną spółką-matką a jej oddziałami za granicą arbitralnie ustalanych cen wewnętrznych korporacji, znacznie odbiegających od cen rynkowych. Dotyczy to zarówno cen bieżącego zaopatrzenia materiałowego, jak i wyposażenia technicznego, na co zwracają uwagę autorzy badający działalność inwestorów zagranicznych w Polsce (por. Kitowski 2007).

Istotnym zagadnieniem badawczym na gruncie nauk geograficznych w procesie zmian funkcjonowania przedsiębiorstw jest analiza wpływu zmian technologicznych na jakość środowiska. Daje się w tym zakresie zauważyć odstępowanie przez geografów tego pola badawczego przedstawicielom nauk technicznych (inżynierom środowiska), chociaż kierunek fizjograficzny, którego przedstawiciele zajmowali się relacjami przemysł-środowisko, w badaniach geograficznych zajmował kiedyś znaczące miejsce. Powodem takiego stanu rzeczy są zapewne trudności w dostępie do szczegółowych danych, szczególnie po rezygnacji z funkcjonowania list największych krajowych i wojewódzkich trucicieli środowiska, o których dostępne były szczegółowe dane. Oficjalna statystyka publiczna ogranicza się jedynie do podawania zbiorczych danych o emisji zanieczyszczeń przez zakłady szczególnie uciążliwe dla środowiska, które dostępne są tylko dla całego kraju i na poziomie województw. Chociaż wiele przedsiębiorstw przygotowuje i publikuje szczegółowe dane dotyczące oddziaływania na środowisko, dane te są często bardzo ogólne i mało wiarygodne, gdyż generalnie przedsiębiorstwo chce przedstawić się w jak najlepszym ekologicznym świetle. Szczególnie ważna wydaje się ocena oddziaływania na środowisko nowych inwestycji i produkcji nowych wyrobów, badacze stoją jednak tutaj przed poważną barierą braku dostępu do danych umożliwiających takie analizy.

Zmiany w procesie technologicznym wymuszają odpowiedni dobór dostawców surowca, dlatego analiza zmian funkcjonowania przedsiębiorstw przemysłowych obejmuje także przestrzenne zmiany w źródla zaopatrzenia. Działania te zmierzają w efekcie do podniesienia konkurencyjności produktów i tym samym do utrzymania i rozszerzenia rynków zbytu. Kolejnym ważnym problemem badawczym są więc przestrzenne zmiany w kierunkach zbytu. W ramach tej problematyki konieczne wydaje się m.in. podjęcie próby odpowiedzi na pytanie, czy z przejęciem przedsiębiorstwa przez koncern zagraniczny nastąpiło istotne rozszerzenie międzynarodowych rynków zbytu, dzięki wprowadzeniu asortymentu produkcji przedsiębiorstwa do sieci sprzedaży koncernu. Wydaje się, że problematyka zmian przestrzennych powiązań pasywnych i aktywnych przedsiębiorstw przemysłowych, powinna zajmować znaczące miejsce w badaniach geograficznych, ze względu właśnie na ten wybitnie przestrzenny charakter. Dostrzega się jednak marginalizację tego aspektu funkcjonowania przedsiębiorstw $\mathrm{w}$ analizach prowadzonych zarówno na gruncie nauk ekonomicznych (co raczej dziwić nie powinno), jak i geograficznych. Wynika to zapewne z trudności w dostępie do danych statystycznych, które są co prawda dostępne, ale w ujęciu krajowym bądź 
regionalnym, jako element handlu zagranicznego (dane o strukturze eksportu i importu itp.). Dane na poziomie przedsiębiorstwa są często nieosiągalne, gdyż baza danych o dostawcach i odbiorcach stanowi czasem jedną z największych tajemnic handlowych firmy. Tymczasem brak analiz powiązań przestrzennych na poziomie przedsiębiorstwa bardzo często prowadzi do nieprecyzyjnych lub nawet czasem mylnych wniosków w analizach sektorowych prowadzonych w ujęciu krajowym. Szczegółowe badania autora (Rachwał 2007) wykazały, że zmiany powiązań przestrzennych w zakresie dostaw i zbytu nie zawsze wynikają z czysto ekonomicznych przesłanek mających na celu podniesienie efektywności, ale często innych, pozaekonomicznych powodów, których poznanie możliwe jest tylko podczas bezpośrednich badań w przedsiębiorstwie.

Dzięki zmianom w poziomie i strukturach zatrudnienia, technologii i asortymencie produkcji, źródłach zaopatrzenia i kierunkach zbytu, korzystnym przemianom powinna ulec struktura kosztów i w efekcie wzrosnąć poziom rentowności. Podejmowane prace badawcze nad funkcjonowaniem przedsiębiorstw na gruncie nauk geograficznych muszą więc obejmować aspekt ekonomiczny zmian. Koszty produkcji należą do podstawowej kategorii ekonomicznej, która jest poddawana analizie ekonomicznej. Poziom i struktura kosztów odzwierciedla jakość pracy w działalności przedsiębiorstwa oraz wpływa na konkurencyjność jego produktów w otoczeniu rynkowym. Analiza kosztów przedsiębiorstwa w układzie rodzajowym pozwala kierownictwu na planowanie i realizowanie odpowiednich przedsięwzięć oraz sprawne zarządzanie i kontrolowanie działalności (Nowak 2001). W analizie kosztów przydatny jest wskaźnik poziomu kosztów, określający udział poniesionych kosztów w przychodach ze sprzedaży, zaliczany do grupy wskaźników rentowności obrotu'.

W analizie zmian struktury kosztów pewną przeszkodą są dwa różne wzorce sprawozdań finansowych, jakie może stosować zgodnie z polskimi standardami rachunkowości przedsiębiorstw. Tylko w jednym z nich są szczegółowo wyróżnione koszty w układzie rodzajowym. Problem niestety tkwi w tym, że dostępne oficjalne dane finansowe - jeśli są - to wg rodzajów wyróżnionych zgodnie z ustawą o rachunkowości. Trudności więc pojawiają się w przypadku konieczności analizy struktury w innym ujęciu, np. uwzględniającej koszty prac badawczo-rozwojowych, które są istotne z punktu widzenia wzrostu konkurencyjności przedsiębiorstwa. W tym przypadku konieczne są badania mające na celu ustalenie kosztów innego rodzaju, które są potrzebne z punktu widzenia przedmiotu i celu prowadzonej analizy zmian funkcjonowania.

Oceniając zmiany zachowań przedsiębiorstw przemysłowych w procesie transformacji należy odpowiedzieć na pytanie, jakie są efekty finansowe przeprowadzonych zmian? ${ }^{7}$ W szczególności należy postawić sobie pytanie, w jakim czasie od rozpoczęcia procesu restrukturyzacji i pod wpływem jakich działań działalność przedsiębiorstwa zaczęła przynosić zyski? W celu oceny efektów finansowych restrukturyzacji przedsiębiorstw można posłużyć się powszechnie stosowanymi wskaźnikami wyniku finansowego przedsiębiorstw (Nowak 2001; Nalepka 2000; por. Kitowski 1998a,1998b,1999, 2004). W celu syntetycznej oceny

${ }^{6}$ Obliczany wg wzoru: $\mathrm{Wpk}=\mathrm{K} / \mathrm{P}$ x100\%, gdzie $\mathrm{K}$ - koszty sprzedaży ogółem, $\mathrm{P}$ - przychód ze sprzedaży. Wartość wskaźnika poniżej $100 \%$ świadczy o rentowności przedsiębiorstwa. Im niższy wskaźnik, tym rentowność większa. Użycie tego wskaźnika pozwala na uniezależnienie się od zmian wartości pieniądza w czasie.

${ }^{7}$ Wszechstronny, rozbudowany model oceny kondycji finansowej przedsiębiorstwa w kontekście badań geograficznych prezentuje i szerzej omawia w swoich pracach J. Kitowski (1998a,1998b,1999, 2004). 
ekonomiczno-finansowej przedsiębiorstw można posłużyć się także wskaźnikami rentowności obrotu (netto i brutto) oraz produktywności całkowitej. Użycie tych wskaźników pozwala na porównanie efektów restrukturyzacji przedsiębiorstw, zróżnicowanych pod względem potencjału i charakteru prowadzonej działalności ${ }^{8}$.

Analiza zebranego materiału powinna zmierzać do wyróżnienia typów zachowań badanych przedsiębiorstw przemysłowych. W wyniku przeprowadzonej analizy empirycznej zmian struktur własnościowo-organizacyjnych, zatrudnienia, zmian technologicznych i asortymentowych produkcji, powiązań przestrzenno-produkcyjnych oraz wybranych elementów analizy finansowej przedsiębiorstw przemysłowych Polski Południowo-Wschodniej wyróżniono 3 typy i 3 podtypy zachowań przedsiębiorstw przemysłowych w procesie transformacji gospodarczej":

TYP A - przedsiębiorstwa rozwijające się, które zakończyły pierwszy etap restrukturyzacji;

podtyp A1 - przedsiębiorstwa, które dzięki wymianie lub modernizacji linii technologicznych weszły na ścieżkę trwałego rozwoju;

podtyp A2 - przedsiębiorstwa, których dalszy trwały rozwój zależny jest od dokończenia modernizacji lub wymiany reszty przestarzałego parku maszynowego;

TYP B - przedsiębiorstwa nadal poszukujące dróg rozwoju, które nie zakończyły jeszcze pierwszego etapu restrukturyzacji (naprawczej);

podtyp B1 - przedsiębiorstwa, które dzięki przeprowadzonym dużym zmianom technologicznym mają szansę na przejście do etapu restrukturyzacji rozwojowej;

podtyp B2 - przedsiębiorstwa, które ze względu na małe zmiany technologiczne mają szanse przejścia do dalszego etapu restrukturyzacji tylko pod warunkiem znalezienia źródeł finansowania inwestycji technologicznych, w przeciwnym razie grozi im upadek;

TYP C - przedsiębiorstwa zanikające, które nie przeszły pomyślnie procesu restrukturyzacji,

podtyp C1 - przedsiębiorstwa upadające, w stosunku do których pod koniec okresu badawczego trwało postępowanie upadłościowe (na bazie ich majątku możliwe jest częściowe wznowienie produkcji);

podtyp C2 - przedsiębiorstwa upadłe (zakończony proces upadłościowy)

Wyróżnione typy zachowań różnicują przedsiębiorstwa na takie, które w swoim procesie transformacji wykorzystały nowe uwarunkowania i takie, które - w wyniku słabego rozpoznania mechanizmów kształtujących - nie wykorzystały szans czy wreszcie poprzez wadliwe wykorzystanie instrumentów prawnych doprowadziły do zjawisk patologicznych i ich recesji. Ponieważ wiele innych przedsiębiorstw, najczęściej tych znajdujących się w trudnej sytuacji finansowej, w najbliższym czasie musi zostać poddanych procesom restrukturyzacji, mającym na celu podniesienie poziomu konkurencyjności ich produktów, wydaje się celowe określenie ich zachowań w świetle przyjętej typologii celem przyjęcia najlepszych dla nich rozwiązań, np. w zakresie wyboru inwestorów strategicznych i włączenia się w międzyna-

${ }^{8}$ Szczegółowe omówienie metod analizy statystycznej różnego typu wskaźników dotyczących funkcjonowania przedsiębiorstwa można znaleźć m.in. w pracy zbiorowej pod red. E. Nowaka (2001).

${ }^{9}$ Wyróżnione typy zostały szczegółowiej omówione i zegzemplifikowane we wcześniejszej pracy autora (Rachwał 2006). 
rodowe, aktywne i pasywne sieci powiązań technologicznych, rynkowych, organizacyjnych i kapitałowych.

W świetle szybkich przemian w gospodarce światowej i integracji Polski ze strukturami europejskimi istotnym problemem badawczym jest określenie dalszych wariantów zachowań badanych przedsiębiorstw. Istotna wydaje się bowiem odpowiedź na pytanie, czy przeprowadzone zmiany w funkcjonowaniu przedsiębiorstw pozwolą na zajęcie i utrzymanie pozycji konkurencyjnej przedsiębiorstw na krajowym, europejskim i światowym rynku. Podjęcie próby określania wariantów rozwoju i dalszych zmian przedsiębiorstw może więc być dużym wkładem o charakterze aplikacyjnym w badanie procesów zmian funkcjonowania przedsiębiorstw. Wydaje się, że identyfikacja tych wariantów rozwoju jest możliwa tylko dzięki podjęciu przedstawionych w niniejszej pracy całościowych badań nad problematyką funkcjonowania przedsiębiorstw.

\section{PROBLEM DOSTĘPU DO DANYCH I OCENY ICH JAKOŚCI}

Na zakończenie rozważań nad problematyką badawczą funkcjonowania przedsiębiorstw przemysłowych niezbędne wydaje się poruszenie problemu dostępności i jakości pozyskiwanych danych. Nie ma wątpliwości, że efekty badań terenowych prowadzonych poprzez bezpośredni wywiad w przedsiębiorstwach lub przygotowane ankiety uzależnione są od przychylności kierownictwa przedsiębiorstw, stąd zakres czasowy i merytoryczny pozyskanych danych dla poszczególnych przedsiębiorstw jest zróżnicowany. Nie trzeba przekonywać, że skuteczność bezpośredniego, osobistego pozyskiwania danych w porównaniu z ankietą wysłaną pocztą tradycyjną bądź elektroniczną jest o wiele większa. Jeśli chodzi o udostępnianie danych, to przedsiębiorstwa najchętniej przekazują te dane, które i tak muszą być obowiązkowo upublicznione, dotyczy to przede wszystkim przedsiębiorstw notowanych na giełdzie papierów wartościowych bądź dużych przedsiębiorstw, które mają obowiązek drukowania swoich corocznych sprawozdań finansowych w Monitorze Polskim B. Jakość tych danych jest z reguły bardzo dobra, gdyż służą one do publikowania raportów kwartalnych, półrocznych i rocznych, które są badane przez biegłych rewidentów. Nawet i w nich zdarzają się jednak pewne niezgodności danych dotyczących niektórych cech (np. zatrudnienia) za te same lata. Pewien problem występuje w sytuacji, gdy przedsiębiorstwo przestaje być notowane na giełdzie papierów wartościowych. Wyjście z giełdy najczęściej jest właśnie podyktowane chęcią zwolnienia się z obowiązku upubliczniania danych o funkcjonowaniu, dlatego stawia to badającego w sytuacji, w której trudno mu uzyskać porównywalne dane w tych zakresach.

W sytuacji gdy przedsiębiorstwo nie jest zobligowane do oficjalnego publikowania raportów ze swojej działalności, dane pozyskane z przedsiębiorstw są z reguły fragmentaryczne i nie we wszystkich latach opracowywane według tej samej metodologii. Istotny wpływ na zmianę metodologii, zakres przedmiotowy i udostępnianie danych na temat przedsiębiorstw ma proces prywatyzacji i przejęcie przedsiębiorstwa przez inwestora strategicznego, $\mathrm{w}$ tym szczególnie w przypadku przejęcia przedsiębiorstwa przez inwestora zagranicznego. Należy zwrócić uwagę, że bardzo często przejęcie przedsiębiorstwa przez inwestora zagranicznego oznaczało całkowity zakaz udostępniania nawet podstawowych danych. Z sytuacją taką wielokrotnie spotkano się podczas prowadzonych prac badawczych. Dlatego przy pozyski- 
waniu danych dotyczących przedsiębiorstw konieczne jest często posłużenie się dodatkowo informacjami zebranymi w ramach tzw. białego wywiadu, ze stron internetowych przedsiębiorstw, materiałami marketingowo-informacyjnymi, informacjami giełdowymi, prospektami emisyjnymi akcji, publikowanymi danymi i analizami w prasie (np. listy 500 bądź 1000 największych przedsiębiorstw, przede wszystkim „Rzeczpospolitej”, „Polityki” i „Życia Gospodarczego", analizami domów maklerskich itp.), baz teleadresowych (np. TeleAdreson, HBI). Należy jednak zwrócić uwagę, że bazy teleadresowe są dobre dla ogólnego zorientowania się w profilu działalności przedsiębiorstw, w znikomym stopniu przydatne są do analizy jego funkcjonowania ze względu na ogólnikowość zawartych w nim danych, a często brak wiarygodnych podstawowych informacji np. o zatrudnieniu czy strukturze własnościowej. Część informacji może także pochodzić z informacji prasowych, z czasopism o charakterze ekonomicznym lub działów gospodarczych wiodących dzienników. Niektóre dane mogą być pozyskane z artykułów naukowych i innych publikacji (np. raportów Inspekcji Ochrony Środowiska) lub informacji ustnych różnych instytucji (np. w wojewódzkich bądź powiatowych urzędach pracy). Dobrym źródłem są również obowiązkowe sprawozdania finansowe publikowane w Monitorze Polskim B przez średnie i duże przedsiębiorstwa. Zgodnie z art. 64 pkt. 4 Ustawy o rachunkowości, mają taki obowiązek spółki akcyjne i podmioty prowadzące działalność gospodarczą, które spełniają dwa z poniższych warunków:

- zatrudniają w przeliczeniu na pełne etaty co najmniej 50 osób,

- mają sumę aktywów bilansu o wartości co najmniej 2,5 mln euro,

- mają przychód netto o wartości co najmniej $5 \mathrm{mln}$ euro.

W praktyce jednak okazuje się, że nie wszystkie firmy spełniają ten ustawowy obowiązek.

W przypadku gdy uzyskane w trakcie badań dane pochodzą z oficjalnych raportów bądź wewnętrznych analiz i raportów danych komórek organizacyjnych (np. dla zarządu) należy przyjąć, że ich wiarygodność i jakość jest bardzo wysoka. Nieco ostrożniej należy traktować informacje prasowe, tym bardziej, jeśli autor artykułu powoływał się na źródła nieoficjalne lub sugerował, że dane zostały pozyskane dzięki dziennikarskiemu „specjalnemu” śledztwu. Należy jednak podkreślić, że dzięki takim dziennikarskim artykułom zostają bardzo często wyjaśnione patologiczne sytuacje w procesie funkcjonowania przedsiębiorstw (czego dobrym przykładem są np. badane przez autora Zakłady Mięsne „Nisko”). Wartość takich artykułów jest dosyć wysoka w porównaniu ze skąpymi informacjami udzielanymi pod presją ,zmowy milczenia”, z jaką bardzo często spotyka się badający ze strony pracowników (w obawie o miejsca pracy lub udział w różnych nieformalnych układach). Zebrany materiał może być czasem niejednolity jakościowo i w wielu wypadkach nieporównywalny, co wpływa na zastosowanie metod analizy typu case study. Wobec braku dostępu do oficjalnej statystyki dotyczącej pojedynczych przedsiębiorstw (ze względu na tajemnicę statystyczną i w wielu przypadkach niegromadzenie danych na dany temat) należy przyjąć, że zebrane w ten sposób materiały stanowią dobrą, rzetelną podstawę do analizy podjętej problematyki. Wskazuje to jednocześnie na potrzebę zmian systemowych w polskiej statystyce publicznej, w celu likwidacji wymienionych barier, co powinno przyczynić się do wzrostu ilości i jakości prowadzonych badań. Należy jednak podkreślić, że niedostatki statystyki publicznej może w pewnym sensie zrekompensować upór badającego.

Przeprowadzone rozważania, jak się wydaje, wskazały na aktualność i ważność podejmowanej problematyki badawczej zmian funkcjonowania przedsiębiorstw oraz na duże zalety całościowego podejścia do tego problemu badawczego, uwzględniające wszystkie ważne aspekty funkcjonowania przedsiębiorstwa, wreszcie na konieczność większego uwzględnie- 
nia kwestii ekonomicznych, gdyż procesy zmian nie są celem samym w sobie, ale powinny prowadzić do wzrostu efektywności i konkurencyjności przedsiębiorstwa, które wyrażają się wskaźnikami ekonomicznymi.

\section{Literatura}

Belka M. 2001, Doświadczenia polskiej transformacji - mikroekonomiczne podstawy i makroekonomiczne uwarunkowania, [w:] Restrukturyzacja przedsiębiorstw w procesie transformacji gospodarki polskiej, t. I, red. E. Mączyńska, INE PAN, Wydawnictwo DIG, Warszawa

Białasiewicz M., Buczkowski T. 1996, Restrukturyzacja przedsiębiorstw i jej skutki na przyktadzie niektórych przedsiębiorstw Szczecina, Zeszyty Naukowe Uniwersytetu Szczecińskiego nr 172, Prace IEiOP nr 34 „Przedsiębiorstwo w procesie transformacji”, s. 183-201

Borowiecki R. (red.), 1992, Prywatyzacja przedsiębiorstw. Formy - sposoby realizacji - doświadczenia, Warszawa-Kraków

Borowiecki R. (red.), 1996, Restrukturyzacja w procesie przekształceń i rozwoju przedsiębiorstwa, AE w Krakowie, Kraków

Borowiecki R. (red.), 1997, Restrukturyzacja a konkurencyjność przedsiębiorstw, KEiOP AE w Krakowie, Kraków

Borowiecki R. (red.), 1994, Restrukturyzacja przedsiębiorstw w procesie transformacji rynkowej, Wyd. „Fogra”, Kraków.

Borowiecki R. (red.), 1998, Restrukturyzacja a poprawa efektywności gospodarowania w przedsiębiorstwie, KEiOP AE w Krakowie, Kraków

Borowiecki R. (red.), 1999a, Restructuring of the national economy under the systemic transformation, Zakamycze, Warsaw-Cracow

Borowiecki R. (red.), 1999b, Wyzwania rozwojowe a restrukturyzacja przedsiębiorstw, KEiOP AE w Krakowie, Kraków

Borowiecki R. (red.), 2003, Managment of organizations during economic integration and globalization, Oficyna Wydawnicza „Abrys”, Warsaw-Cracow

Chojnicki Z. 1996, Geografia społeczno-ekonomiczna wobec transformacji systemowej w Polsce, „Przegląd Geograficzny”, t. LXVIII, z. 1-2, s. 19-29

Chomątowska M., Waligórska A. 1996, Zmiany wielkości i struktury zatrudnienia i sprzedaży ZPO „Vistula” w okresie ich restrukturyzacji własnościowej, [w:] Restrukturyzacja w procesie przekształceń i rozwoju przedsiębiorstwa, red. R. Borowiecki, AE w Krakowie, Kraków, s. 569-579

Czapliński P. 2000, Przemyst drzewny na Pomorzu Środkowym w procesie przeobrażeń gospodarczych, [w:] Problemy transformacji struktur przemyslowych $w$ procesie przechodzenia do gospodarki rynkowej, red. Z. Zioło, Prace Komisji Geografii Przemysłu PTG nr 1, Warszawa-Kraków s. $67-76$

Czapliński P. 2002, Zmiany $w$ funkcjonowaniu przemysh $w$ warunkach poprzedzajacych wprowadzenia gospodarki rynkowej w regionie stupskim, [w:] Geograficzne uwarunkowania rozwoju Matopolski, red. Z. Górka, A. Jelonek, PTG O. Kraków, Koło PTG w Nowym Sączu, Instytut Geografii i Gospodarki Przestrzennej UJ, Instytut Geografii AP, Kraków, s. 317-322

Czapliński P. 2003, „Problemy transformacji przemysłu regionu słupskiego w procesie zmian systemu gospodarowania”, niepublikowany maszynopis rozprawy doktorskiej, Instytut Geografii AP, Kraków

Czerwieniec E. 1997, Polityka państwa wobec inwestycji zagranicznych w okresie transformacji, [w:] Przedsiębiorstwo na rynkach międzynarodowych, Zeszyty Naukowe AE w Poznaniu, nr 241, s. $55-68$

Domański B. 1997, Geografia przedsiębiorstw - niedoceniany nurt badań w polskiej geografii ekonomicznej, [w:] Geografia - Człowiek - Gospodarka, red. B. Domański, Instytut Geografii i Gospodarki Przestrzennej UJ, Kraków, s. 101-112 
Domański B. 2001, Kapitał zagraniczny w przemyśle Polski, Instytut Geografii i Gospodarki Przestrzennej UJ, Kraków

Dutkowski M., Michalski T., Sagan I., Stryjakiewicz T. 1999, Polska geografia społeczno-ekonomiczna wobec transformacji, globalizacji i schytku modernizmu, [w:] Geografia polska u progu trzeciego tysiaclecia, tom IV, red. B. Domański, W. Widacki, Instytut Geografii UJ, Kraków, s. 135-148

Dyhdalewicz A. 1999, Usprawnienia rachunku kosztów w wybranych przedsiębiorstwach przemystowych $w$ regionie pótnocno-wschodniej Polski, Studia Regionalne nr 1, WSE, Białystok, s. $233-245$

Filipczuk J., Soroka P., Wach T. 1998, Zmiany w zachowaniach polskich przedsiębiorstw i firm w warunkach transformacji ustrojowej, „Przegląd Organizacji” 1998, nr 3, s. 25-30

Gierańczyk W. 2006, Rola przedsiębiorstw w polskiej gospodarce w okresie transformacji ustrojowej, [w:] Międzynarodowe uwarunkowania rozwoju przemystu, red. Z. Zioło i T. Rachwał, Prace Komisji Geografii Przemysłu PTG nr 8, Warszawa-Kraków, s. 91-99

Gierszewska G., Wawrzyniak B. 2001, Globalizacja. Wyzwania dla zarzqdzania strategicznego, Poltext, Warszawa.

Godziszewski B. 2001, Szanse i zagrożenia dla polskich przedsiębiorstw zwiqzane z Uniq Europejska, [w:] Konkurencyjność gospodarki Polski w dobie integracji z Uniq Europejskq i globalizacji, tom II, SGH, Warszawa, s. 281-293

Hamrol M., Stróżak R. 1998, Tempo, rozmiary i efektywność przekształceń własnościowych przedsiębiorstw województwa poznańskiego, [w:] Badania nad funkcjonowaniem przedsiębiorstw i jego otoczeniem, red. E. Kurtys, Zeszyty Naukowe AE w Poznaniu, nr 260, s. 55-72

Herma J. 1966, Dojazdy do pracy w Polsce Poludniowej, WSP, Kraków

Kasiewicz S. 2001, Koszt kapitatu a konkurencyjność polskich przedsiębiorstw w latach 90-tych, [w:] Konkurencyjność gospodarki Polski w dobie integracji z Uniq Europejskq i globalizacji, t. II, SGH, Warszawa, s. 183-194

Kitowski J. 1988, Rola dojazdów do pracy w gospodarce narodowej, UMCS, Lublin

Kitowski J. 1989, Ekonomiczne skutki dojazdów do pracy w przedsiębiorstwach, „Ekonomika i Organizacja Przedsiębiorstwa", nr 4, s. 18-21

Kitowski J. 1998a, Ocena kondycji ekonomiczno-finansowej organizacji gospodarczych polskiej części euroregionów, [w:] Metody uogólnień w modelowaniu transgranicznych przepływów transportowych, red. S. Dziadek, Wyd. AE im. K. Adamieckiego, Katowice, s. 31-41

Kitowski J. 1998b, Ocena kondycji ekonomiczno-finansowej przedsiębiorstw przemystowych polskiej części euroregionów, [w:] Czynniki i bariery regionalnej wspótpracy transgranicznej - próba syntezy, red. J. Kitowski, Rzeszów, s. 95-110

Kitowski J. 1999, Międzynarodowe implikacje kondycji finansowej spótek giełdowych regionu transgranicznego (na przyktadzie województwa podkarpackiego), [w:] Problematyka geopolityczna Europy Środkowej i Wschodniej, red. J. Kitowski, Rzeszów, s. 475-499

Kitowski J. 2004, Appraisal of Financial Condition of Businesses in the Podkarpackie Province at Threshold of Poland's Integration with the European Union, [w:] Central and Eastern Europe at the European Union - an Opening Balance, Geopolitical Studies vol. 12, Polish Academy of Sciences, Institute of Geography and Spatial Organization, Warsaw, s. 427-439

Kitowski J., 2007, Przemiany struktury przestrzennej specjalnych stref ekonomicznych $w$ Polsce, [w:] Procesy transformacji spoleczno-ekonomicznych i przyrodniczych struktur przestrzennych, Ksiega Jubileuszowa dedykowana Profesorowi Zbigniewowi Zioło, red. J. Lach, M. Borowiec, T. Rachwał, Wydawnictwo Naukowe AP, Kraków, s. 257-276

Klamecka-Roszkowska G. 1999, Polityka ustalania cen w wybranych przedsiębiorstwach województwa białostockiego, Studia Regionalne nr 1, WSE Białystok, s. 227-232

Kołodko G. 1999, Od szoku do terapii. Ekonomia i polityka transformacji, Poltext, Warszawa

Kostrubiec B. 2006, Delokalizacja przedsiębiorstw - przejaw światowej samoregulacji, [w:] Międzynarodowe uwarunkowania rozwoju przemystu, red. Z. Zioło i T. Rachwał, Prace Komisji Geografii Przemysłu PTG nr 8, Warszawa-Kraków, s. 37-46 
Kotowicz-Jawor J. 1997, Bariery rozwoju przedsiębiorstw w okresie transformacji, [w:] Transformacja gospodarki. Spojrzenie retrospektywne, red. W. Jakóbik, Instytut Studiów Politycznych PAN i Fundacja im. Fiedricha Eberta, Warszawa

Kowalczuk-Jakubowska D., Malewicz A. 1995, Restrukturyzacja jako technika ratowania i rozwoju przedsiębiorstwa, Instytut Organizacji i Zarządzania w Przemyśle ORGMASZ, Warszawa

Koźmiński A.K. 1998, Odrabianie zaległości. Zmiany w organizacji i zarzadzaniu w bytym bloku socjalistycznym, WN PWN, Warszawa

Krawczyk J.P. 1996, To samo i nie to samo, „Nowe Życie Gospodarcze”, nr 17, s. 16-17

Kudełko M. 1994, Przemiany struktury kosztów produkcji w polskich kopalniach węgla kamiennego w procesie transformacji systemu gospodarowania, [w:] Funkcjonowanie przedsiębiorstw przemystowych $w$ zmieniajacych się warunkach gospodarowania, COMSN, Komisja Geografii Przemysłu PTG, Kraków-Warszawa, s. 105-113

Kurek M. 1996, Uwarunkowania i kierunki restrukturyzacji przedsiębiorstw przemystu farmaceutycznego (na przykładzie Przedsiębiorstwa Farmaceutycznego ,,Polfa” w Rzeszowie S. A.), Rzeszowskie Zeszyty Naukowe „Prawo-Ekonomia”, t. XX, UMCS filia w Rzeszowie, s. 129-140

Kwaśny J. 1997, Inwestycje jako podstawa procesu naprawczego w Zakladach Azotowych Tarnów S.A., „Gospodarka Narodowa” nr 10, s. 66-76

Langer W. 1998, Działalność promocyjna przedsiębiorstw (na przykładzie firmy „Zelmer”), Zeszyty Naukowe WSIiZ w Rzeszowie, nr 1, s. 65-74

Liberska B. (red.), 2002, Globalizacja, mechanizmy $i$ wyzwania, PWE, Warszawa

Lipowski A. 1997, Polityka przemysłowa a wzrost konkurencyjności, WN PWN, Warszawa

Makieła Z. 2002, Wyniki realizacji programów restrukturyzacji górnictwa wegla kamiennego po 1989 r., [w:] Problemy transformacji struktur przemystowych, red. Z. Zioło, Prace Komisji Geografii Przemysłu PTG nr 4, Rzeszów-Warszawa-Kraków, s. 57-66

May K. 2008, Adaptacja przedsiębiorstw przemystowych - przykład Łodzi, [w:] Procesy transformacji układów przestrzennych przemystu na tle zmieniajacego się otoczenia, red. Z. Zioło, T. Rachwał, Prace Komisji Geografii Przemysłu PTG nr 10, Warszawa-Kraków, s. 154-172

Mączyńska E. (red.), 2001, Restrukturyzacja przedsiębiorstw w procesie transformacji gospodarki polskiej, t. I-II, INE PAN, Wydawnictwo DIG, Warszawa

Mikołajewicz Z. 2001, Przedmiotowa struktura inwestycji przemystowych wyrazem przemian strukturalnych w polskim przemyśle, [w:] Problemy przemian struktur przestrzennych przemystu, red. Z. Zioło, Prace Komisji Geografii Przemysłu PTG nr 2, Warszawa-Kraków, s. 21-34

Misztal S. 1994, Wpływ wielkości zakładów i przedsiębiorstw przemysłowych na ich funkcjonowanie w okresie przejściowym do gospodarki rynkowej, [w:] Funkcjonowanie przedsiębiorstw przemysłowych w zmieniajacych się warunkach gospodarowania, red. Z. Zioło, COMSN, Komisja Geografii Przemysłu PTG, Kraków-Warszawa, s. 164-171

Misztal S. 1997, Rozwój geografii przemystu i jej problematyki badawczej, [w:] Geografia-Człowiek - Gospodarka, red. B. Domański, Instytut Geografii UJ, Kraków, s. 115-123

Mościbrodzka K. 2000, Finansowanie sektora przedsiębiorstw w okresie transformacji (rozwiazania alternatywne), Instytut Finansów przy Wyższej Szkole Ubezpieczeń i Bankowości, Warszawa

Nalepka A. 2000, Ustalanie i ocena skutków restrukturyzacji przedsiębiorstwa, [w:] Strategie wzrostu produktywności firmy. Materiały konferencji naukowej (Zakopane-Kościelisko, 22-24 IX 2000 r.), red. A. Stabryła, AE, Kraków, s. 409-418

Nowak E. (red.), 2001, Metody statystyczne w analizie działalności przedsiębiorstwa, PWE, Warszawa

Pakuła L. 1967, Uwagi o prowadzeniu ćwiczeń terenowych z geografii przemystu, [w:] Wybrane zagadnienia z metodyki ćwiczeń terenowych z geografii ekonomicznej, Prace z Dydaktyki Szkoły Wyższej, z. 4, Wydawnictwo Naukowe WSP, Kraków

Pakuła L. 2003, Tendencje restrukturyzacji przemystu Górnoślaskiego Okręgu Przemysłowego w dobie transformacji, [w:] Przemyst w procesie globalizacji, red. Z. Zioło i Z. Makieła, Prace Komisji Geografii Przemysłu PTG nr 6, Warszawa-Kraków, s. 59-66 
Parysek J.J. 1994, Zachowania przestrzenne przedsiębiorstw przemysłowych w nowych warunkach spoleczno-ustrojowych (na przykladzie Swarzędzkich Fabryk Mebli S.A.), [w:] Funkcjonowanie przedsiębiorstw przemystowych $w$ zmieniajacych się warunkach gospodarowania, red. Z. Zioło, COMSN, Komisja Geografii Przemysłu PTG, Kraków-Warszawa, s. 22-30

Pączka S. 1994a, Badania dotyczace funkcjonowania przedsiębiorstw przemystowych $w$ zmieniajacych się warunkach gospodarowania w Polsce, [w:] Funkcjonowanie przedsiębiorstw przemystowych w zmieniajacych sie warunkach gospodarowania, red. Z. Zioło, COMSN, Komisja Geografii Przemysłu PTG, Kraków-Warszawa, s. 172-18

Pączka S. 1994b, Problematyka badawcza zachowań przestrzennych przemystu $w$ zmieniajacych się warunkach gospodarowania $w$ Polsce, [w:] Zachowania przestrzenne przemystu w zmieniajacych sie warunkach gospodarowania, red. Z. Zioło, COMSN, Komisja Geografii Przemysłu PTG, Kraków-Warszaw, s. 39-47

Polanowski L. 1991, Badania zbytu w przedsiębiorstwach podstawqich sukcesów na rynku, Rzeszowskie Zeszyty Naukowe „Prawo-Ekonomia”, tom X, UMCS filia w Rzeszowie, s. 232-271

Rachwał T. 2001, Problematyka kwestionariusza do badań zmian funkcjonowania przedsiębiorstwa przemystowego $w$ okresie transformacji systemu gospodarowania, [w:] Problemy przemian struktur przestrzennych przemystu, red. Z. Zioło, Prace Komisji Geografii Przemysłu PTG nr 2, Warszawa-Kraków, s. 49-57

Rachwał T. 2006, Efekty restrukturyzacji wybranych przedsiębiorstw przemyslowych Polski Poludniowo-Wschodniej, [w:] Efekty restrukturyzacji polskiej przestrzeni przemystowej, red. Z. Zioło, T. Rachwał, Prace Komisji Geografii Przemysłu PTG nr 9, Warszawa-Kraków, s. 98-115

Rachwał T. 2007. Zmiany powiazań przestrzennych przedsiębiorstw przemysłowych Polski PołudniowoWschodniej w latach transformacji systemu gospodarowania, [w:] Procesy transformacji spoteczno-ekonomicznych i przyrodniczych struktur przestrzennych. Księga Jubileuszowa dedykowana Profesorowi Zbigniewowi Zioło, red. J. Lach, M. Borowiec, T. Rachwał, Wydawnictwo Naukowe AP, Kraków, s. 325-351

Rosati D.K. 1998, Polska droga do rynku, PWE, Warszawa

Rutkowska A. 1998, Lokalizacja firm na miejskich obszarach przemystowych (na przykładzie Stużewca Przemystowego), [w:] Wspótczesne uwarunkowania lokalizacji przemystu w Polsce, red. K. Kuciński, Szkoła Główna Handlowa, Warszawa, s. 123-140

Rutkowska A. 2000, Miejski obszar przemystowy jako środowisko lokalizacji firm (na przykładzie Stużewca Przemysłowego), Szkoła Główna Handlowa, Warszawa

Rydz E. 2007, Ocena procesu transformacji przemystu na Pomorzu Środkowym, [w:] Procesy transformacji społeczno-ekonomicznych i przyrodniczych struktur przestrzennych. Księga Jubileuszowa dedykowana Profesorowi Zbigniewowi Zioło, red. J. Lach, M. Borowiec, T. Rachwał, Wydawnictwo Naukowe AP, Kraków, s. 286-305

Rydz. E. Szymańska W. 2002, Funkcjonowanie zakładów przemystu obuwniczego regionu stupskiego w zmieniajacych się warunkach gospodarowania, [w:] Problemy transformacji struktur przemysłowych, red.Z.Zioło, Prace Komisji Geografii Przemysłu PTG nr 4, Warszawa-Kraków-Rzeszów, s. $43-56$

Sapijaszka Z. 1997, Restrukturyzacja przedsiębiorstwa. Szanse i ograniczenia, WN PWN, Warszawa

Sieniawska K. 1994, Ocena jakości produkcji w Sanockiej Fabryce Autobusów „Autosan” S.A. (w latach 1987-1991), Rzeszowskie Zeszyty Naukowe Prawo-Ekonomia, t. XVI, s. 407-414

Stępień B. 2001, Procesy przystosowawcze przedsiębiorstw postsocjalistycznych do warunków rynkowych, Akademia Ekonomiczna w Poznaniu, Poznań

Stryjakiewicz T. 1994, Problematyka przedsiębiorstwa przemystowego w pracach Komisji Przemian Przemystu i Komisji Organizacji Przestrzeni Przemystowej Międzynarodowej Unii Geograficznej, [w:] Funkcjonowanie przedsiębiorstw przemystowych w zmieniajacych sie warunkach gospo- 
darowania, red. Z. Zioło, COMSN, Komisja Geografii Przemysłu PTG, Kraków-Warszawa, s. $50-56$

Stryjakiewicz T. 1998, Problemy geografii ekonomicznej w Polsce w okresie transformacji, [w:] Przemiany społeczno-gospodarcze Polski lat dziewięćdziesiatych, pod red. J.J. Paryska i H. Rogackiego, Bogucki Wydawnictwo Naukowe, Poznań, s. 295-307

Stryjakiewicz T. 1999, Adaptacja przestrzenna przemystu w Polsce $w$ warunkach transformacji, WN UAM, Poznań

Stryjakiewicz T. 2001, Orientacje teoretyczno-metodologiczne w geografii przemystu a transformacja gospodarki, [w:] Problemy przemian struktur przemystowych w procesie wdrażania regut gospodarki rynkowej, red. Z. Zioło, Prace Komisji Geografii Przemysłu PTG nr 3, Warszawa-KrakówRzeszów, s. 14-27

Sudoł S. 1996, Proces reorientacji polskich przedsiębiorstw z kanonów gospodarki nakazowo-rozdzielczej na logike gospodarki rynkowej, [w:] Nowe kierunki w zarzqdzaniu przedsiębiorstwem - doświadczenia praktyczne, Prace Naukowe AE we Wrocławiu, nr 725, Wrocław, s. 9-19

Sudoł S. 1997, Perspektywy rozwoju polskich przedsiębiorstw przemysłowych $i$ budowlanych, „Ekonomika i Organizacja Przedsiębiorstwa”, nr 8 (571), s. 4-6

Sudoł S., Karaszewski W. (red.), 1996, Proces transformacji rynkowej przedsiębiorstw (w świetle badań empirycznych), Wyd. UMK, Toruń

Sudoł S., Matuszak M. (red.), 2002, Przyczyny rozwoju i upadku polskich przedsiębiorstw przemysłowych w okresie transformacji ustrojowej 1990-1998, Wyd. UMK, Toruń

Tkocz M. 1994, Przeksztatcenia własnościowe przedsiębiorstw państwowych w woj. katowickim, [w:] Problemy transformacji struktur regionalnych $w$ procesie przechodzenia do gospodarki rynkowej, red. J. Kitowski, Z. Zioło, Warszawa-Kraków-Rzeszów, s. 325-336

Tkocz M. 1996, Funkcjonowanie kopalń węgla kamiennego w warunkach ksztaltowania się gospodarki rynkowej, [w:] Wplyw procesów transformacji gospodarki narodowej na funkcjonowanie jednostek gospodarczych i układów przestrzennych, red. Z. Zioło, Komisja Geografii Przemysłu PTG, Instytut Geografii WSP w Krakowie, Warszawa-Kraków, s. 60-68

Tkocz M. 2001, Restrukturyzacja przemystu regionu tradycyjnego, Prace Naukowe Uniwersytetu Śląskiego w Katowicach nr 1998, Katowice

Tobolska A. 2006, Nowy model organizacji i funkcjonowania starych przedsiębiorstw przemysłowych, [w:] Efekty restrukturyzacji polskiej przestrzeni przemystowej, red. Z. Zioło, T. Rachwał, Prace Komisji Geografii Przemysłu PTG nr 9, Warszawa-Kraków, s. 83-97

Torspecken H.-D. 1993, Finansowanie przedsiębiorstw w warunkach gospodarki rynkowej, Zachodniopomorska Szkoła Biznesu przy Uniwersytecie Szczecińskim, Szczecin

Troc M. 1991a, Ćwiczenia z geografii przemystu, WN WSP, Kraków

Troc M. 1991b, Kwestionariusz do badania zakładu przemystu rolno-spożywczego, [w:] Problemy przemystu rolno-spożywczego w badaniach geograficznych, red. Z. Zioło, COMSN, Komisja Geografii Przemysłu PTG, Kraków-Warszawa

Wiedermann K. 2006, „Czynniki i skutki rozwoju przemysłu motoryzacyjnego w skali lokalnej i regionalnej na przykładzie województwa śląskiego", niepublikowany maszynopis rozprawy doktorskiej, Instytut Geografii i Gospodarki Przestrzennej UJ, Kraków.

Wiedermann K. 2007, Regionalne efekty mnożnikowe rozwoju przemyshu motoryzacyjnego w aktywizacji gospodarczej województwa ślaskiego, [w:] Rola przedsiębiorczości w aktywizacji gospodarczej, Wydawnictwo „Nowa Era”, Warszawa-Kraków, s. 24-34

Wiedermann K. 2008, Czynniki i skutki rozwoju przemystu motoryzacyjnego na terenie województwa ślaskiego, [w:] Procesy transformacji układów przestrzennych przemystu na tle zmieniajacego się otoczenia, red. Z. Zioło, T. Rachwał, Prace Komisji Geografii Przemysłu PTG nr 10, WarszawaKraków, s. 93-108

Wieloński A. 2003, Przemyst Nowej Gospodarki, [w:] Przemyst w procesie globalizacji, red. Z. Zioło, Z. Makieła, Prace Komisji Geografii Przemysłu PTG nr 6, Warszawa-Kraków 2003, s. 21-25 
Wieloński A., Durydiwka M. 1994, Przemyst w Polsce w warunkach przejścia do gospodarki rynkowej i integracji z Europq Zachodnia, „Czasopismo Geograficzne”, LXV, z. 3-4, s. 317-325

Wojtyna A. 1994, Polityka przemystowa a instytucjonalne ramy restrukturyzacji w Polsce, „Gospodarka Narodowa" Nr 12 (56), s. 6-14

Wypchło W. 1994, Funkcjonowanie Fabryki Samochodów Ciężarowych „Star” w Starachowicach w nowych warunkach gospodarowania, [w:] Funkcjonowanie przedsiębiorstw przemysłowych w zmieniajacych się warunkach gospodarowania, red. Z. Zioło, COMSN, Komisja Geografii Przemysłu PTG, Kraków-Warszawa, s. 148-157

Zawadzki M. 2001, Potrzeby kapitałowe i źródta finansowania działalności przedsiębiorstw w okresie transformacji, [w:] Restrukturyzacja przedsiębiorstw w procesie transformacji gospodarki polskiej, red. E. Mączyńska, t. I, INE PAN, Wydawnictwo DIG, Warszawa, s. 191-206

Zioło Z. 1992, Wspótczesne przesłanki rozwoju geografii przemystu w warunkach zmieniajacego się systemu gospodarowania, [w:] Geografia przemystu w warunkach nowego systemu gospodarowania - problemy badawcze i ich odzwierciedlenie w ksztatceniu nauczycieli, red. Z. Zioło, COMSN w Krakowie, Komisja Geografii Przemysłu PTG, Kraków-Warszawa, s. 6-19

Zioło Z. 1999, Transformacja struktur subregionalnych Polski Poludniowo-Wschodniej w okresie zmian systemu gospodarowania, Prace Komisji Nauk Ekonomicznych nr 24, PAN oddz. w Krakowie, Kraków

Zioło Z. 2000, Problemy integracji międzynarodowej przemystu w procesie zmian systemu gospodarowania, [w:] Problemy transformacji struktur przemystowych w procesie przechodzenia do gospodarki rynkowej, red. Z. Zioło, Prace Komisji Geografii Przemysłu PTG nr 1, Warszawa-Kraków, s. $13-22$

Zioło Z. 2001, Wspótczesne tendencje rozwoju przemystu i ich problematyka badawcza, [w:] Problemy przemian struktur przestrzennych przemystu, red. Z. Zioło. Prace Komisji Geografii Przemysłu PTG nr 2, Warszawa-Kraków, s. 9-20

Zioło Z. 2003, Ksztaltowanie się przedsiębiorstw przemystowych w procesie globalizacji, [w:] Przemyst w procesie globalizacji, red. Z. Zioło, Z. Makieła, Prace Komisji Geografii Przemysłu PTG nr 6, Warszawa-Kraków 2003, s. 9-20

Zioło Z. 2006a, Zróżnicowanie światowej przestrzeni przemysłowej w świetle koncentracji siedzib zarzq̨ów wiodacych korporacji, [w:] Międzynarodowe uwarunkowania rozwoju przemystu, Prace Komisji Geografii Przemysłu PTG Nr 8, red. Z. Zioło i T. Rachwał, Warszawa-Kraków, s. 9-26

Zioło Z. 2006b, Problematyka badawcza efektów restrukturyzacji polskiej przestrzeni przemystowej, [w:] Efekty restrukturyzacji polskiej przestrzeni przemystowej, red. Z. Zioło, T. Rachwał, Prace Komisji Geografii Przemysłu PTG nr 9, Warszawa-Kraków, s. 11-19

Zioło Z. 2008, Procesy transformacji przemysłowych układów przestrzennych na tle zmieniajacego się otoczenia, [w:] Procesy transformacji układów przestrzennych przemystu na tle zmieniajacego się otoczenia, red. Z. Zioło, T. Rachwał, Prace Komisji Geografii Przemysłu PTG nr 10, Warszawa-Kraków, s. 11-22

Zorska A. 1998a, Ku globalizacji? Przemiany w korporacjach transnarodowych i w gospodarce światowej, WN PWN, Warszawa

Żukrowska K. 2001, Polska gospodarka w warunkach globalizacji gospodarki światowej, [w:] Globalizacja, red. J. Klich, Instytut Studiów Strategicznych, Wyd. PSB, Kraków, s. 149-172 
Załącznik nr 1

\section{Kwestionariusz do badań zmian funkcjonowania przedsiębiorstwa przemysłowego w okresie transformacji systemu gospodarowania}

\section{Zagadnienia ogólne}

1.1. Nazwa przedsiębiorstwa (zmiany nazwy, w tym po prywatyzacji i wejściu inwestora strategicznego)

1.2. Organizacja przedsiębiorstwa (liczba zakładów, oddziałów, filii, własnych przedstawicielstw handlowych, siedziba zarządu)

1.3. Zmiany struktury organizacyjnej (na podstawie schematów organizacyjnych)

1.4. Przynależność do sekcji/działu/grupy przemysłu i profil działalności wg klas PKD

1.5. Forma organizacyjno-prawna (np. spółka z o.o., akcyjna, societas europea)

1.6. Typ własności (struktura udziałów w \%), w przypadku prywatyzacji przedsiębiorstwa państwowego - czas i forma (ścieżka prywatyzacji)

1.7. Funkcje spełniane w strukturze gospodarczej i znaczenie produkcyjne (lokalne, regionalne, ogólnopolskie, światowe)

2. Lokalizacja przedsiębiorstwa

2.1. Adres - przynależność administracyjna (zmiany lokalizacji zakładów, oddziałów i siedziby zarządu)

2.2. Położenie w stosunku do centrum miasta (peryferyjne, w centrum itd.)

2.3. Położenie fizjograficzne

2.3.1. rzeźba terenu, warunki geologiczne, typy gleb

2.3.2. w stosunku do bogactw naturalnych (odległość od surowca, jeśli jest to istotne)

2.3.3. w stosunku do sieci rzecznej, zbiorników wodnych itp. (jeśli potrzebuje dużo wody)

2.4. Położenie w stosunku do infrastruktury transportowej (drogi, koleje, ropociagi, gazociagi, linie energetyczne itp.)

2.5. Lokalizacja w stosunku do innych przedsiębiorstw (kooperantów i konkurencji)

2.6. Położenie w specjalnej strefie ekonomicznej lub parku technologicznym (naukowo-przemysłowym) i korzyści z tego wynikające

2.7. Inne korzyści i zagrożenia wynikające z lokalizacji

3. Proces kształtowania się przedsiębiorstwa w rozwoju historycznym

3.1. Czynniki lokalizacji i rozwoju (w tym rok założenia)

3.2. Ważniejsze etapy rozwoju przedsiębiorstwa (w tym fuzje, przejęcia i podziały, ekspansja na rynki zagraniczne, budowa nowych zakładów produkcyjnych)

4. Charakterystyka inwestora strategicznego (w tym zagranicznego)

4.1. Nazwa inwestora/-ów,

4.2. Kraj pochodzenia w przypadku inwestora zagranicznego (ew. międzynarodowy)

4.3. Siedziba zarządu koncernu

4.4. Struktura organizacyjna koncernu (na świecie)

4.5. Rozmieszczenie i struktura wielkościowa zakładów koncernu na świecie (wg liczby zatrudnionych lub wysokości obrotów) oraz ich asortyment produkcji

5. Powiązania inwestora strategicznego (zagranicznego) z przedsiębiorstwem

5.1. Rok zainwestowania kapitału (przejęcia kontroli nad przedsiębiorstwem) 
5.2. Czynniki (motywy) wejścia kapitału (atrakcyjność przedsiębiorstwa dla kapitału zagranicznego)

5.3. Wielkość zainwestowanego kapitału (w tym na zakup akcji i rzeczywiste inwestycje w produkcję)

5.4. Zobowiązania inwestycyjne (m.in. docelowa wielkość inwestycji, gwarancje zatrudnienia, socjalne itp.)

5.5. Zmiany w strukturze organizacyjnej przedsiębiorstwa (dostosowanie do struktury koncernu)

6. Zagadnienia stosunków pracy

6.1. Zmiany w poziomie zatrudnienia (w tym po zakończeniu okresu ewentualnej gwarancji zatrudnienia), z uwzględnieniem spadku bądź wzrostu zatrudnienia w wyniku zmian organizacyjnych (wydzielenie bądź łączenie jednostek zależnych)

6.2. Zwolnienia grupowe

6.3. Nowe przyjęcia do pracy (na jakie stanowiska)

6.4. Zmiany w strukturach kierowniczych przedsiębiorstwa (jakie stanowiska zostały przejęte przez pracowników inwestora)

6.5. Zmiany w kulturze pracy i metodach zarządzania

6.6. Zmiany stosunku pracowników nieprodukcyjnych (umysłowych) do bezpośrednio produkcyjnych

6.7. Zmiany w strukturze wykształcenia pracowników, stażu pracy, wieku i płci

6.8. Przynależność pracowników do związków zawodowych (udział \% w stosunku do ogółu zatrudnionych)

6.9. Zmiany wysokości płac (średnia na danych stanowiskach, ew. w stosunku do innych przedsiębiorstw lub średniej krajowej)

6.10. Miejsce zamieszkania pracowników - zmiany kierunków dojazdów do pracy (ew. koszty dowozu pracowników)

6.11. Przemiany jakościowe w zasobach pracy (zmiany w systemie szkoleń pracowników oraz metodach zarządzania)

6.12. Działalność socjalna przedsiębiorstwa (w tym działania na rzecz pracowników wykraczające poza obowiązki pracodawcy wynikające z przepisów prawa)

7. Wielkość $\mathrm{i}$ asortyment produkcji

7.1. Zmiany wielkości produkcji (w jednostkach produkowanego asortymentu)

7.2. Zmiany wartości produkcji sprzedanej ( $w$ zł lub $€$ )

7.3. Zmiany profilu produkcji przedsiębiorstwa na podstawie struktury asortymentowej produkcji wg wartości sprzedaży (w zł lub $€$ ) lub ilości (w jednostkach produkowanego asortymentu)

7.4. Zmiany w głębokości i szerokości asortymentu

7.5. Dostosowanie produkowanego asortymentu do globalnej strategii inwestora

8. Proces technologiczny i jakość produkcji

8.1. Etapy procesu technologicznego - droga surowca do uzyskania postaci użytecznej (od stadium przygotowawczego, przez proces właściwy do stadium końcowego - pakowania)

8.2. Mechanizacja procesu produkcji na poszczególnych etapach, komputeryzacja i inne innowacje w technologii wytwarzania

8.3. Park maszynowy, stopień zużycia maszyn i urządzeń (nowe inwestycje)

8.4. Zmiany wartości produkcyjnego majątku trwałego

8.5. Transport wewnątrz zakładów produkcyjnych (ew. pomiędzy nimi)

8.6. Działalność innowacyjna i badawczo-rozwojowa (czy jest prowadzona i w jakim zakresie) 
8.7. Wdrażanie norm zarządzania jakością (np. serii ISO 9000 i równoważnych serii EN 29000)

8.8. Wpływ zmian technologicznych na zmniejszenie negatywnej presji przedsiębiorstwa na środowisko (spełnianie norm środowiskowych ISO 14001, inne certyfikaty ekologicznej produkcji)

9. Zaopatrzenie w materiały (surowiec) do produkcji i zakup usług

9.1. Zmiany źródeł zaopatrzenia materiałowego - miejsce, wartość (w zł lub $€$ ) lub udział \%

9.2. Własne źródła surowca, ich wielkość i udział \% w ogóle dostaw

9.3. Zaopatrzenie przedsiębiorstwa w półfabrykaty (w tym dostarczanie przez koncern inwestora własnych półfabrykatów do produkcji i ich udział w wartości ogółu dostaw)

9.4. Zaopatrzenie w źródła energii i wodę (jeśli są ważnym czynnikiem produkcji)

9.5. Zaopatrzenie w opakowania

9.6. Zaopatrzenie w maszyny i urządzenia do produkcji (skąd są sprowadzane)

9.7. Powiązania z podmiotami świadczącymi usługi dla przedsiębiorstwa (np. transportowo-spedycyjne, informatyczne, doradcze, marketingowe)

9.8. Charakter kontraktów (krótko-, długoterminowe) z dostawcami i usługodawcami.

10. Zbyt produkcji

10.1. Zmiany stosunku wartości sprzedaży krajowej do sprzedaży eksportowej (ew. wg udziałów \% w ogóle sprzedaży)

10.2. Zmiany w wartości lub wielkości zbytu wg miejscowości (regionów, województw itp.)

10.3. Zmiany kierunków eksportu (wg państw) na podstawie wartości lub wielkości zbytu

10.4. Struktura przestrzenna rynków zbytu (lokalny, regionalny, ogólnokrajowy, europejski itd.)

10.5. Przyczyny stałości lub zmienności kierunków zbytu

10.6. Rentowność sprzedaży eksportowej w stosunku do sprzedaży w kraju przyczyny zróżnicowania tej rentowności

10.7. Transport towaru do odbiorców

10.8. Zmiany w zakresie techniki i organizacji sprzedaży - rozbudowa działu marketingu, nowe formy promocji, trudności z pozyskaniem specjalistów od marketingu

10.9. Rozszerzenie rynków zbytu (krajowych i zagranicznych) dzięki pozyskaniu inwestora strategicznego (np. poprzez udostępnienie sieci sprzedaży koncernu)

\section{Zmiany w poziomie i strukturze kosztów produkcji}

11.1. Poziom kosztów (w świetle np. wskaźnika poziomu kosztów)

11.2. Zmiany struktury rodzajowej kosztów (amortyzacja środków trwałych, zużycie materiałów i energii, wynagrodzenia, ubezpieczenia społeczne i inne świadczenia dla pracowników, usługi obce, podatki i opłaty, pozostałe koszty rodzajowe)

11.3. Koszty organizacji i utrzymania własnej sieci sprzedaży oraz na reklamę

11.4. Koszty działalności socjalnej (np. utrzymanie własnych ośrodków wczasowych, dowóz pracowników) i wynikające z działań przedsiębiorstwa w ramach CSR (społecznej odpowiedzialności biznesu)

11.5. Koszty ponoszone na ochronę środowiska (w tym np. kary za zanieczyszczenia, koszt utrzymania urządzeń służących ochronie środowiska) 
11.6. Koszty związane z działalnością innowacyjną i pracami badawczo-rozwojowymi

12. Rentowność produkcji - wyniki finansowe

12.1. Wyniki finansowe działalności ( $w$ świetle rachunku zysków i strat)

12.2. Zwolnienia podatkowe (jeśli sa, na jakiej podstawie)

12.3. Efekty finansowe związane z innowacjami technicznymi (np. komputeryzacja) i technologicznymi

12.4. Wpływ zmiany organizacji pracy (zatrudnienia) na wyniki finansowe

13. Pozytywny i negatywny wpływ na otoczenie

13.1. Efekty mnożnikowe (zaopatrzeniowe i dochodowe) funkcjonowania przedsiębiorstwa

13.2. Wpływ na lokalny i regionalny rynek pracy (w tym stopę bezrobocia i zmiany jakościowe)

13.3. Oddziaływanie na miasto lub okolicę w zakresie rozwoju infrastruktury społecznej i techniczno-ekonomicznej

13.4. Wpływ na rozwój rolnictwa (jeśli branża rolno-spożywcza)

13.5. Wpływ na rozwój firm współpracujących (kooperantów, podwykonawców, dostawców usług - outsourcing, offshoring)

13.6. Powiązania z placówkami naukowymi, badawczo-rozwojowymi i systemem szkolnictwa

13.7. Przekształcenie środowiska geograficznego w związku z rozbudowa przedsiębiorstwa (np. zajmowanie nowych terenów, powstanie form antropogenicznych)

13.8. Zanieczyszczenie środowiska (zmiany udziału przedsiębiorstwa w ogólnej emisji zanieczyszczeń w okolicy)

13.9. Rekultywacja terenów zniszczonych pod wpływem działalności przemysłowej przedsiębiorstwa, rewitalizacja terenów poprzemysłowych należących do przedsiębiorstwa

14. Ocena dotychczasowego procesu zmian oraz perspektywy rozwoju przedsiębiorstwa

14.1. Ocena procesu restrukturyzacji oraz wpływu inwestora strategicznego na funkcjonowanie przedsiębiorstwa (rozwój produkcji, rozszerzenie rynków zbytu itd.) w świetle wypowiedzi kadry zarządzającej oraz pracowników

14.2. Wpływ akcesji Polski do Unii Europejskiej na funkcjonowanie przedsiębiorstwa (szanse i zagrożenia dla przedsiębiorstwa, ew. konkretne straty bądź zyski)

14.3. Terenowe możliwości rozbudowy poszczególnych zakładów przedsiębiorstwa (jeśli istnieje taka potrzeba), zamiary przeniesienia zakładów produkcyjnych w inne miejsce

14.4. Zamiary połączenia się z innymi (lub rozdzielenia), wejścia w spółki, wykup innych przedsiębiorstw, włączenia się w krajowe lub globalne sieci przemysłowe itp.

14.5. Wejście na giełdy papierów wartościowych (polską i zagraniczne)

14.6. Dalsze zmiany w dostosowaniu struktury organizacyjnej do struktury koncernu, w organizacji pracy i metodach zarządzania

14.7. Możliwości w zakresie pozyskania nowych, krajowych i zagranicznych rynków zbytu

14.8. Kierunki dalszego inwestowania i ich uzasadnienie

14.9. Przewidywane wyniki finansowe 


\section{Research problems concerning the functioning of industrial enterprises}

Economic transformation processes in Poland, taking effect under the influence of advancing globalization, trigger extensive changes in the functioning of particular sectors of the national economy, industrial and service enterprises, and institutions. As a result, industrial structures are rebuilt, which is due to changes in functioning of industrial enterprises regarded as the basic elements of the spatial forms of industry concentration. These changes condition the participation of the national industrial enterprises in the global economic processes, and the integration of the Polish industry with the global industry, especially through forming organizational, financial, and technological bonds, and through entering the already-formed market networks of international corporations. Therefore, from the point of view of the analysis of the economic transformation process in Poland, and especially transformation of industrial structures, the research area of functioning of enterprises, which is the focus of this paper, seems an important issue.

In the first part, the author makes an attempt at showing differences between approaches to research problems concerning functioning of enterprises in geographical and economic sciences, and points to the necessity that researchers pay special attention to the conditioning of changes in functioning of enterprises and the sources of financial means for the restructuring. Further, the author presents a modernized questionnaire investigating functioning of an industrial enterprise, outlines the criteria of selection of enterprises for the research, and discusses the range of analysis of changes in enterprises functioning basing on results achieved from empirical studies conducted in south-east Poland. The paper is concluded with a discussion of access to data, and data quality evaluation.

These considerations appear to prove the validity and significance of the undertaken research problems concerning changes in enterprise functioning, to show advantages of a comprehensive approach to this problem area, which includes all important aspects of enterprise functioning, and to point out to the necessity of more extensive inclusion of economic issues in research work conducted in the field of industrial geography, as processes of change are not a goal, but a means that should lead to an increase in efficiency and competitiveness of an enterprise, expressed by economic indexes. 